Historic, Archive Document

Do not assume content reflects current scientific knowledge, policies, or practices. 
62,41

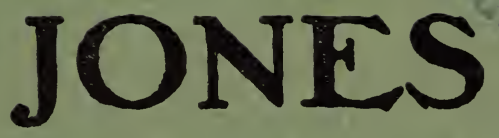

The Seedman

11 N. IONIA S'r.

GRAND RAPIDS, MICH.

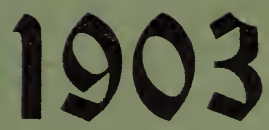

Market Gardeners'

Wholesale

Price List 



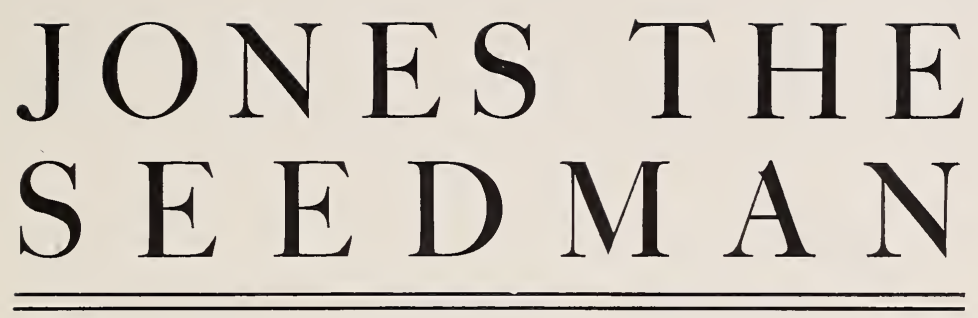

M A R K E T GARDENERS' WHOLESALE PRICE LIST F O R I 9003

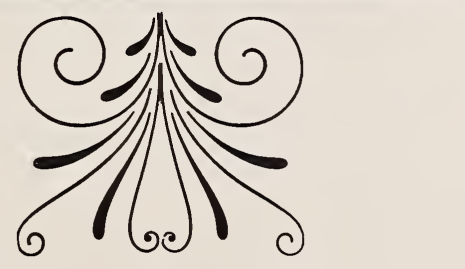

11 NORTH IONIA STREET GRAND RAPIDS, MICHIGAN 


\section{JONES' MARKET GARDENERS' WHOLESALE PRICE LIST FOR 1903}

$A^{\mathrm{LL}}$ of our seeds are tested as to Germinating quality.

The prices herein quoted we will adhere to as far as possible, but we reserve the right to change the price without notice. Many varieties of sweet corn are impossible to obtain and when we sell out will have to remain sold out on those sorts. We buy only from good growers and take every precaution to get the best seeds obtainable, and should they prove not true to name we will replace them with other seeds or refund the money paid.

Purchasers by maill will add to these prices a sufficient amount to cover postage. On quantities of from one-half pound upwards, 8 cents per pound; 15 cents per quart for peas and beans, or 10 cents per quart for sweet corn. All seeds in quarter pounds or ounces prepaid.

Remit by Postoffice Money Order, Express Order or Bank Draft.

\section{J ONES, THE SEEDM A N 1I NORTH IONIA STREET, GRAND RAPIDS, MICHIGAN}




\section{NOVELTIES IN VEGETABLE * SEEDS *}

\section{BEANS.}

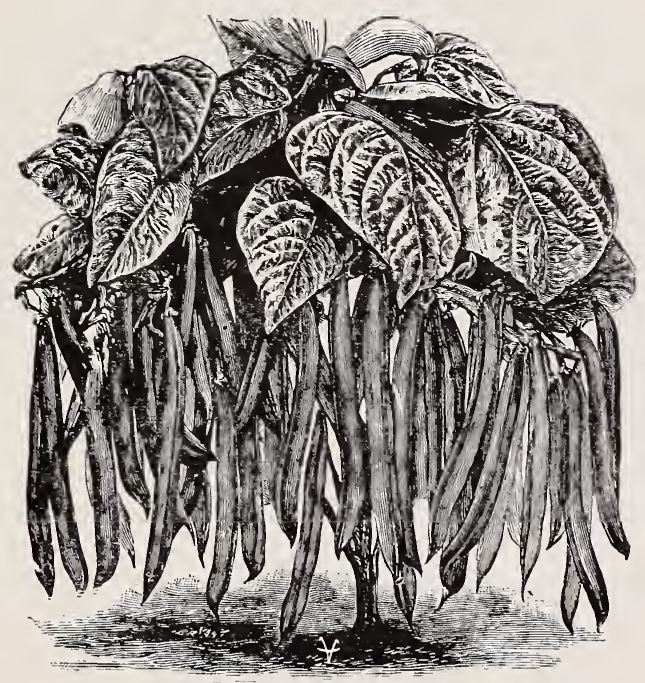

Burpee's Stringless Green Pod. Very early and hardy. For either market or home garden; no other green podded bean is so satistactory. The pods are a rich green, very round and straight, five inches long, solidly meaty, tender and brittle; always entirely stringless even when fully matured.

Giant Stringless Green Pod. This new variety should not be confused with Burpee's Stringless Green Pod. It resembles more closely the Valentine, the pods averaging onethird larger than the latter variety. The plants are of strong growth, the pods five to six inches in length, absolutely stringless, crisp, round, full and fleshy; follows Burpee's Stringless Green Pod. 


\section{BEETS.}

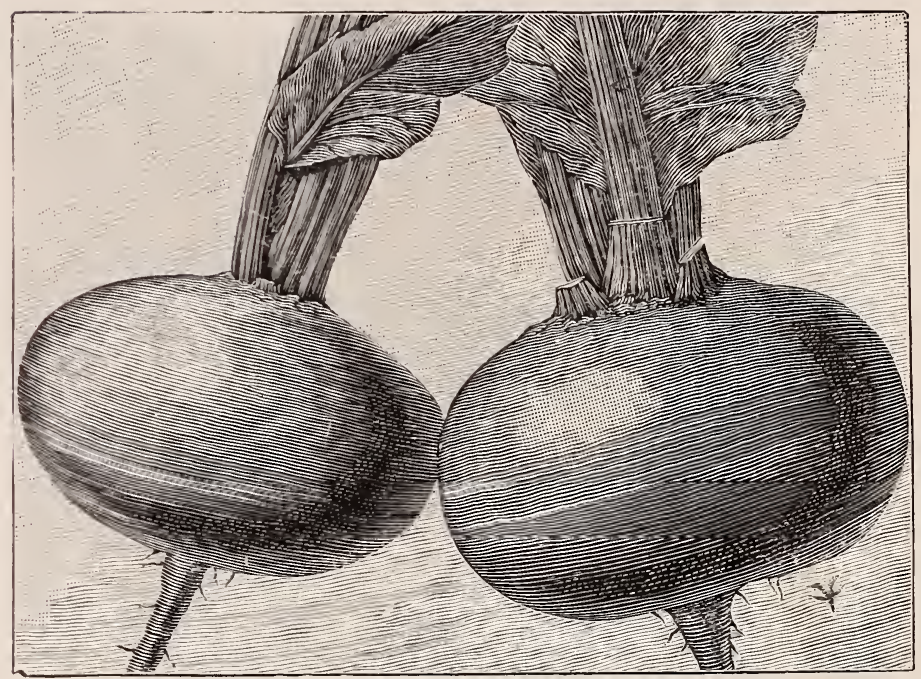

Crosby's Egyptian. The earliest beet on the market, a selection from the Early Egyptian which retains the earliness of the parent stock and has added thickness, giving it a more desirable shape. Color deep red, almost black; sweeter and smoother than the Egyptian. It is a rapid grower and the most desirable sort for early bunching; can be sown as late as July.

Acme. This new variety is just becoming recognized as one of the very best main crop beets. The top is low, spreading, dark color, roots thick, turnip shaped with small tap root. Outside color dark purplish red, flesh crimson and ninety per cent. of the beets have no white zones. It is superior in both shape and color to the Detroit Dark Red, which it resembles, and is a remarkably long keeper. Especially adapted to gardeners and canner's use.

Giant Feeding Sugar Beet or Half Sugar Mangel. This valuable stock beet is the result of careful seed breeding and selection. It has the richness of the sugar beet combined with the size and yield of the mangel. It will yield twice as much as the sugar beet, is much easier handled and keeps better and in every way is more valuable to the farmer; roots are large ovoid in form, very smooth, white in color with small tops. It should be planted closer than mangels. 


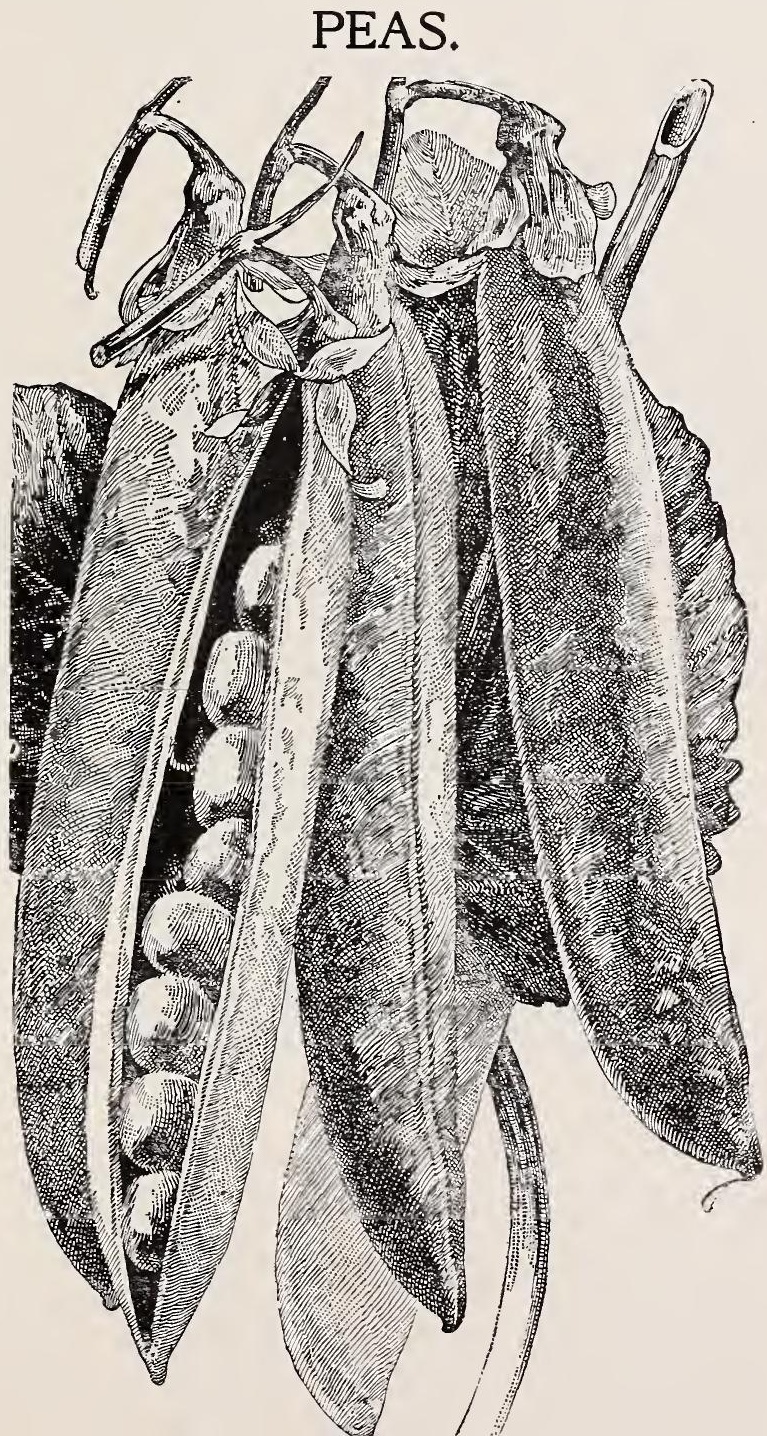




\section{PEAS-CONTINUED.}

Gradus. From the market gardeners' stand point too much cannot be said in praise of the Gradus or Prosperity. It is extra early, being but 2 or 3 days later than the very earliest. Pods very large from 4 to $4 \frac{1}{2}$ inches in length, peas large and handsome and as sweet as the Champion of England. The vine has heavy stems with large dark green leaves and grows from $2 \frac{1}{2}$ to 3 feet high.

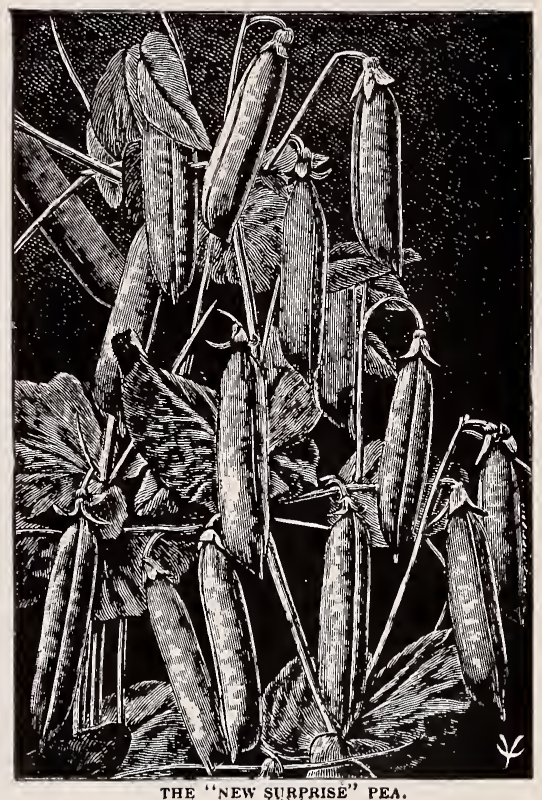

Gregory's Surprise or Eclipse. This is the earliest of all wrinkled peas, fully as early as the Alaska. The vines grow about 18 inches high and require no bushing; a fall cropper. Though equally as early as the smooth sorts it has the delicious sweetness of the wrinkled peas. The pods continue longer in condition for the table than the smooth varieties. The crop matures very evenly so that it can be gathered in one or two pickings. From the more tender character of the wrinkled peas it cannot be planted quite so early as the Alaska or First and Best. 


\section{THE DELICIOUS SQUASH.}

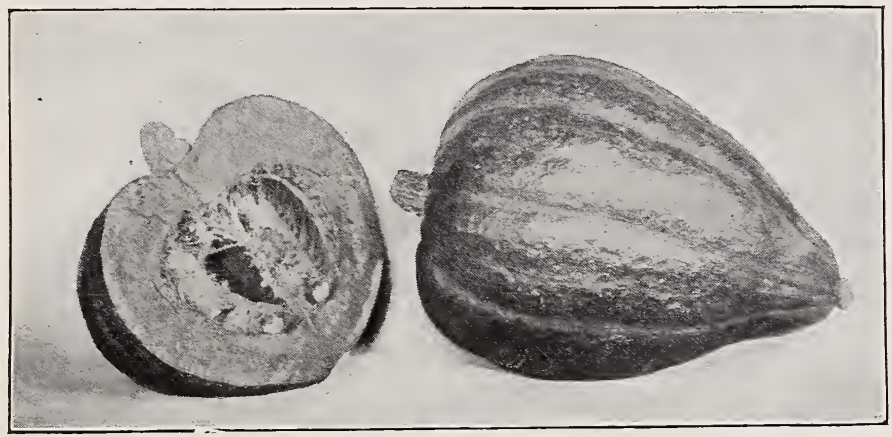

The Delicious is the product of the work of years in careful selection, crossing and isolating by the originator of the old Hubbard and all who have tested the Delicious pronounce it supperior to even the Hubbard when it was at its best a quarter of a century ago. In form the Delicious ranges between the two examples given above. Its color is almost uniformly of a green shade, with occasionally a blue specimen. In size it follows closely the original Hubbard, which weighed between five and ten pounds. In thickness of flesh it surpasses nearly every variety, the color being a dark orange. For table use no squash compares with it in its fineness of grain, dryness, sweetness and exceeding richness of flavor. It is a fall and winter squash, but like the old Hubbard, though at any time excellent, does not acquire its best qualities until winter. Seed of the Delicious will be retailed the coming season in packages only, at fifteen cents each, four for fifty cents.

\section{CUCUMBER.}

Rawson's White Spine. Mr. Rawson selects the specimens for seed stock from the vines saved in the green house in early winter where nothing is allowed to grow except the vines for seed stock. The fruit grows very even in size and regular in form, color dark green, with light spines running from the blossom end. The very best cucumbers for forcing. Nine-tenths of the cucumbers grown in Grand Rapids green houses are grown from this seed. 


\section{CABBAGE.}

(New Savoy-Iron Head.)

Earliest. Large; this is the very best of all the tender and solid, Early Savoy Cabbage. The heads are round, very large, of best flavor and hard as iron. It is the earliest of all. Market gardeners will find it a money maker.

\section{RADISH.}

Scarlet Conical. Absolutely the best forcing radish on account of quick growth, extremely small tops, and the length of time they will stand without becoming pithy. Color brilliant scarlet, shape conical, flavor is all that can be desired and is very tender and brittle; equally as good for outdoor raising as for green house.

\section{TOMATOES.}

Spark's Earliana. The earliest smootb brigbt red Tomato of good size and flavor. A heavy bearer, nearly all of the fruit ripens very early in the season. The tomatoes are a deep scarlet and grow closely together in clusters of from five to eight.

\section{T H I S T L E I N E K I L L S CANADA THISTLES.}




\section{JONES' MARKET GARDENERS' WHOLESALE PRICE LIST FOR 1903}

\section{ASPARAGUS. \\ ROOTS.}

Palmetto, two year old roots

Per 100 Per 1000

$\$ 150 \$ \$ 600$

SEEDS.

Palmetto

$\mathrm{Oz} . \quad \mathrm{I} / \mathrm{lb} . \quad \mathrm{lb}$

Conover's Colossal

$10 \quad 20 \quad 75$

$10 \quad 20 \quad 60$

\section{BEANS.}

(One pint to 100 feet of drill, 1 bushel per acre.)

\section{DWARF SNAP OR BUSH,}

(Green Podded Sorts.)

Burpee's Stringless Green Pod. See novelties.

Qt. 4-Qt. Peck Bush.

Long Yellow Six Weeks. Early, pod long, flat, light green .

$\begin{array}{lllll}25 & 80 & \$ 1 & 50 & \$ 500\end{array}$

Round Yellow Six Weeks. Improved strain of long Yellow Six Weeks, pods not so long but more fleshy and brittle, nearly stringless

$\begin{array}{llllll}20 & 75 & 125 & 4 & 50\end{array}$

Giant Stringless Green Pod. See novelties.

$\begin{array}{llllll}20 & 75 & 1 & 25 & 4 & 50\end{array}$

$20 \quad 75 \quad 150 \quad 500$

Emperor William. Earlier than the Dutch Case Knife, pods very tender and excellent flavor, nearly as long as Dutch Case Knife, a Dwarf Bush Bean

$20 \quad 75 \quad 150 \quad 500$

Refugee or 1000 to 1 . Pods nearly round, pale green, solid, fleshy, brittle with but slight strings.

$20 \quad 75 \quad 125 \quad 450$

Dwarf Horticultural. Vines very productive, pods medium length, cylindrical, covered with splashes of bright red on a yellowish ground, beans very large and easily shelled.

$\begin{array}{llllll}20 & 75 & 1 & 50 & 500\end{array}$

Longfellow. New, pods very long, stringless, vines immensely productive 
BEANS-Continued.

\section{WAX SORTS.}

Dwarf Golden Wax. One of the best early wax varieties, pods long, flat, fleshy, color bright golden.

Challenge Black Wax. Early, round, clear, waxy white, fleshy, crisp, tender and stringless..

German Black Wax. Earliest wax podded bean, pods long,
curved, round, deep golden yellow, meaty, brittle and stringless

Davis' Kidney Wax. Immensely productive, pods very long, straight and handsome; color light yellow, should be picked young
Qt. 4-Qt. Peck Bush.

$\begin{array}{llllll}25 & 90 & \$ 1 & 75 & \$ 7 & 00\end{array}$

$25 \quad 90 \quad 175 \quad 700$

$25 \quad 90 \quad 175 \quad 700$

$25 \quad 90 \quad 175 \quad 700$

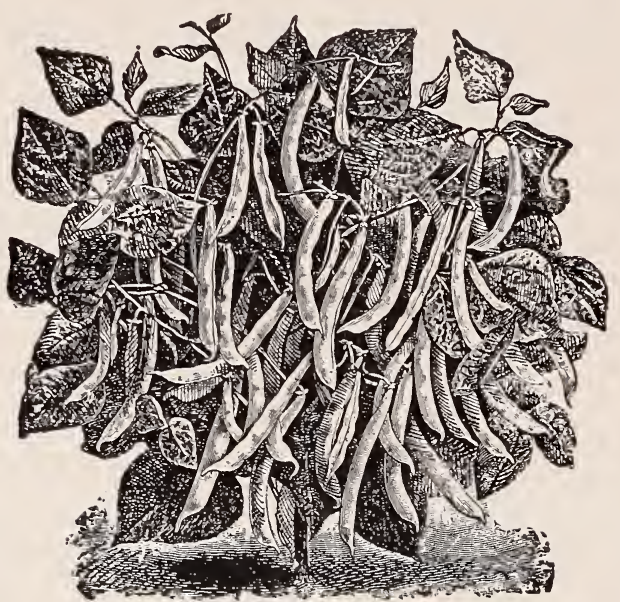

Wardwell's Kidney Wax Beans.

Wardwell's Kidney Wax. Early, good cropper, pods long, straight, fleshy, rich yellow and stringless

$25 \quad 90 \quad 175 \quad 700$

\section{POLE OR RUNNING.}

Seibert's Early Lima. The earliest true pole lima

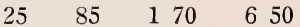

King of the Garden. Late, very productive, large pods containing five or six large well flavored beans..

$\begin{array}{llllll}25 & 85 & 1 & 70 & 650\end{array}$

Dutch Case Knife. Pod long, flat, green, seed white, used largely for slicing and canning.

$\begin{array}{llllll}25 & 75 & 150 & 600\end{array}$




\section{BEANS-CONTINUED.}

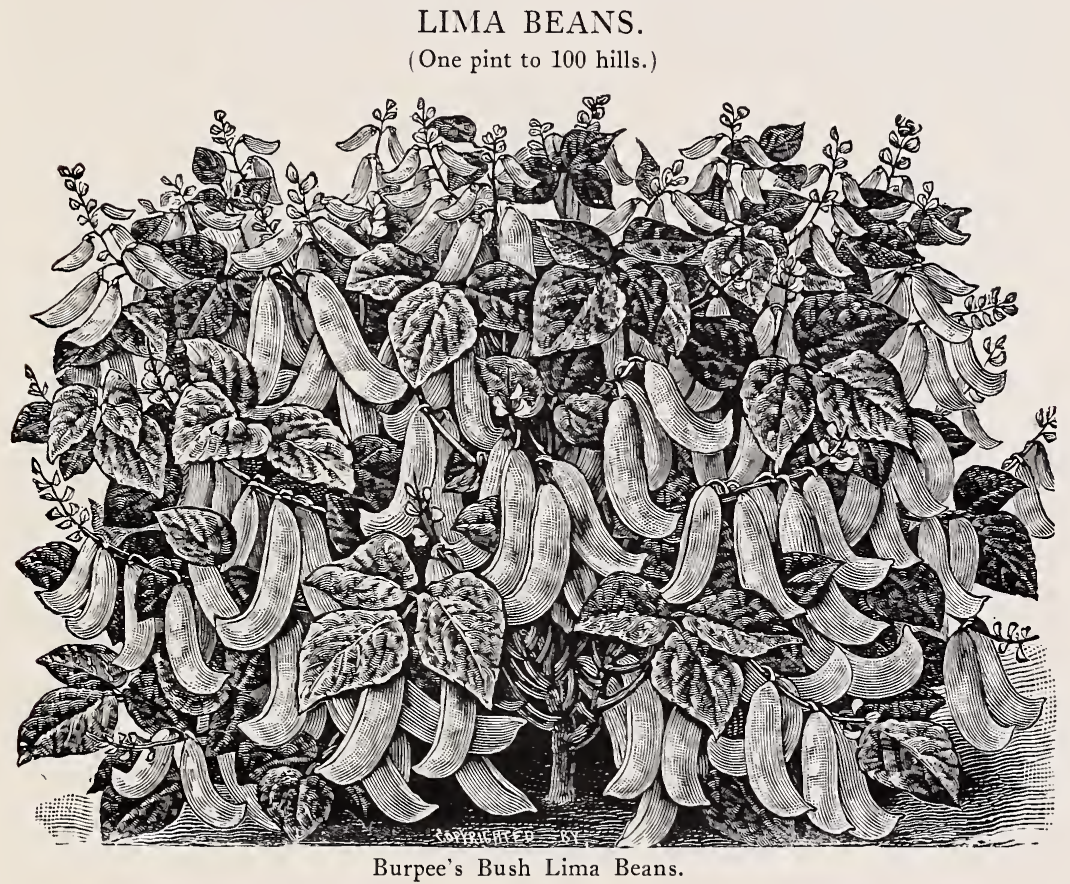

Burpee's Bush Lima. A bush form of true large lima, very productive, bean large and of fine flavor

Qt. 4-Qt. Peck Bush.

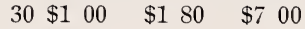

\section{BEETS.}

(One ounce to 100 feet of drill. Seven pounds per acre.)

The color of beets depends largely on the season and cultivation. Richest coloring is developed during cool moist weather. Jones' Crosby's Egyptian. Selected stock, see novelties $\quad \begin{array}{llll}10 & 20 & 70 & \$ 3\end{array}$ Crosby's Egyptian ...

$5 \quad 15 \quad 50 \quad 200$

Eclipse. A superior market garden beet, blood red, very early, excellent for greens and for bunching beets.

$5 \quad 15 \quad 40 \quad 180$

Early Blood Turnip. Not so early as Detroit Dark Red, tops and roots larger

$5 \quad 15 \quad 40 \quad 180$




\section{BEETS-CONTINUED.}

Detroit Dark Red. A favorite sort for bunching; early, dark red, perfect turnip shape, tops small

Oz. $\quad \mathrm{t} / 4-\mathrm{lb}$. lb. $5-\mathrm{lb}$.

Acme. See novelties

$\begin{array}{rrrrr}5 & 15 & 50 & \$ 2 & 25 \\ 10 & 20 & 70 & 3 & 00 \\ 5 & 15 & 50 & 2 & 00 \\ 5 & 15 & 50 & 2 & 00 \\ 5 & 15 & 40 & 1 & 80\end{array}$

Dewing's Blood Turnip. A favorite variety with market gardeners for main crop and winter storing: roots smooth, almost round, outer color dark red, inner color ringed red and white

$\begin{array}{lllll}5 & 15 & 59 & 2 & 00\end{array}$

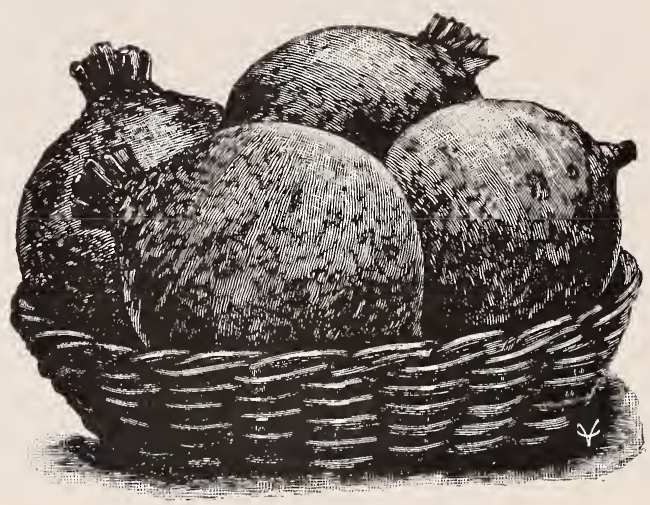

Edmand's Blood Turnip. One of the best main crop beets; tops small, good form, color deep blood red, zoned with lighter shade

$\begin{array}{lllll}5 & 15 & 50 & 2 & 00\end{array}$

Swiss Chard or Sea Kale Beet. Superior to beets for greens; plant forms broad wax like stems which may be used as a salad or pickled

$5 \quad 15 \quad 50$

\section{SUGAR BEETS.}

( 5 to 7 lbs. per acre.)

Giant Feeding Sugar Beet. See novelties

Oz. $\quad \mathrm{r} / 4-\mathrm{lb} . \quad \mathrm{lb} . \quad 5-\mathrm{lb}$.

Lane's Imperial. One of the best for stock feeding

$5 \quad 10 \quad 30 \quad 125$

Vilmorin's Imperial

$5 \quad 10 \quad 30 \quad 125$

Klein's Wanzleben. Best German

$5 \quad 10 \quad 30$

125

$5 \quad 10 \quad 30$ 
BEETS-CONTINUED.

MANGEL WURZEL.

( 5 to 7 lbs. per acre.)

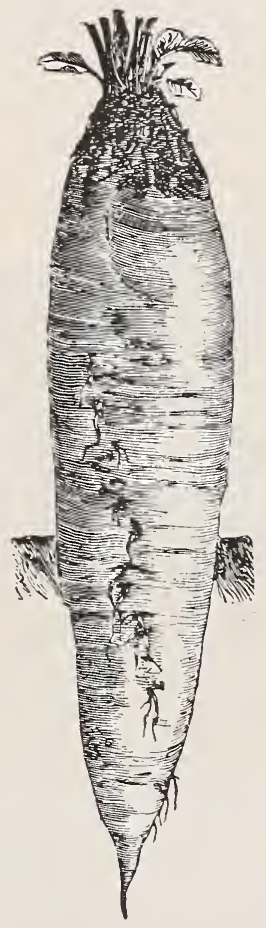

Mammoth Long Red

Oz. 1/4-lb. lb. 5-lb.

Golden Tankard

$\begin{array}{lllll}5 & 10 & 25 & \$ 1 & 00\end{array}$

Orange Globe.

$\begin{array}{lllll}5 & 10 & 25 & 1 & 00\end{array}$

$\begin{array}{lllll}5 & 10 & 25 & 1 & 00\end{array}$

BORECOLE OR KALE.

( $1 \mathrm{oz}$ to 3000 plants.)

Tall Green Curled.

$10 \quad 20 \quad 60$

Dwarf Green Curled.

$10 \quad 20 \quad 60$ 


\section{BROCOLI.}

(1 oz. to 5000 plants.)

Mammoth White

Oz. $\quad \mathrm{I} / 4-\mathrm{lb} . \quad \mathrm{lb}$.

$\begin{array}{llll}30 & 80 & \$ 2 & 00\end{array}$

\section{BRUSSELS SPROUTS.}

(1 oz. to 5000 plants.)

Paris Market

$15 \quad 40 \quad 150$

\section{CABBAGE.}

$1 \mathrm{oz}$. to 2000 plants; $2 \mathrm{oz}$. sown thinly provide enough plants for one acre.

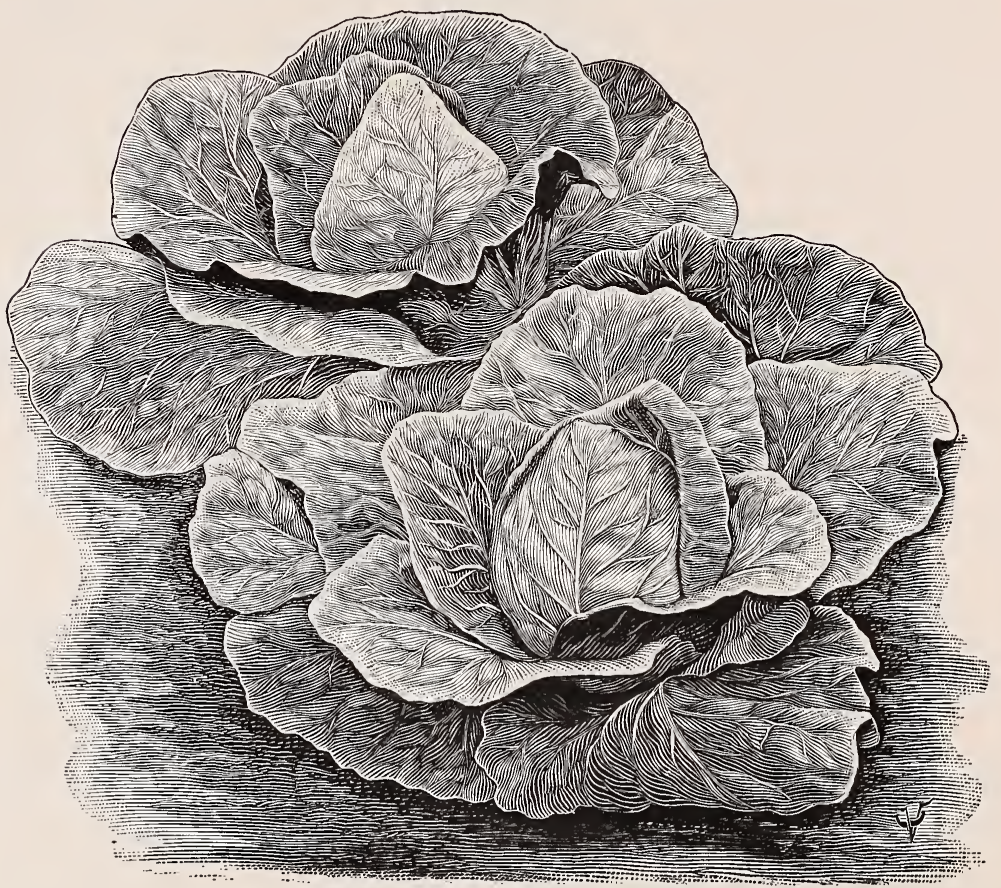

Oz. $\quad \mathrm{T} / \mathrm{A}-\mathrm{lb} . \quad \mathrm{lb}$.

Jones' Earliest Jersey Wakefield. Forms solid heads of fair size; conical in shape with few outside leaves. This is the earliest strain of this variety and is remarkably pure. 


\section{CABBAGE-CONTINUED.}

Charleston or Large Wakefield. A strain of the Wakefield in which the head is larger, a little later and not so pointed; a good cabbage to follow early Jersey Wakefield

Oz. $\quad \frac{1}{4}-\mathrm{Ib} . \quad \mathrm{lb}$.

Early Spring. Nearly as early as Early Jersey Wakefield; heads round, solid, but not large

$25 \quad 75 \quad \$ 250$

$\begin{array}{llll}20 & 75 & 2 & 50\end{array}$

\section{SECOND EARLY.}

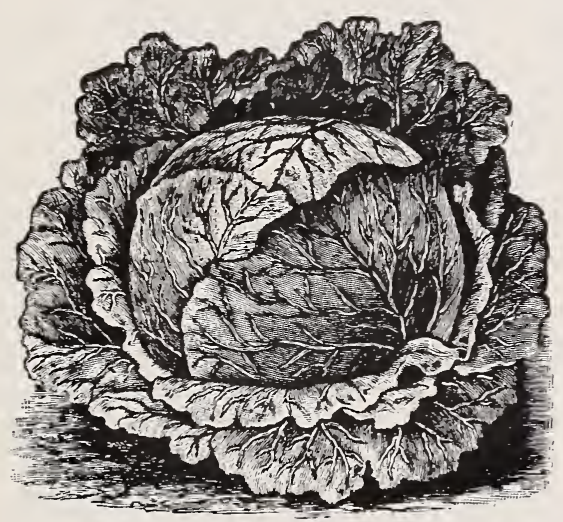

Henderson's Early Summer. Large, round, solid heads, keeps longer without bursting than most of the early sorts; one of the best Second Early Cabbage.

$20 \quad 60 \quad 200$

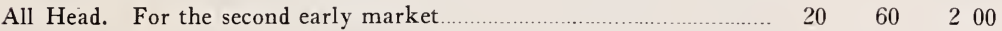

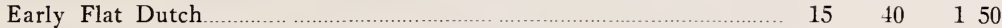

Early Winingstadt. Heads large, cone shaped and solid; very early and sure to head

$20 \quad 60 \quad 200$

All Seasons..

$20 \quad 60 \quad 200$

Henderson's Succession. About 10 days later than Early summer; heads larger and more uniform

$20 \quad 60 \quad 200$

Fottler's Early Brunswick. Earliest of the large heading Drumheads... $\quad \begin{array}{llll}15 & 45 & 150\end{array}$

Fielderkraut..

$\begin{array}{llll}15 & 45 & 1 & 50\end{array}$




\section{CABBAGE-Continued. LATE KINDS.}

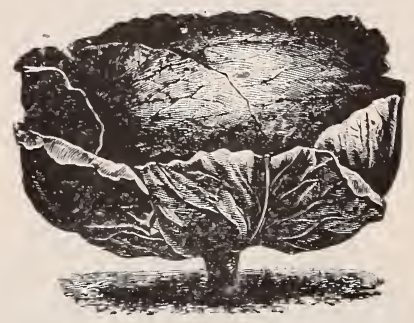

Surehead. Strong, vigorous, uniform, large, solid and quality fine

Oz. $\quad \mathrm{T} / 4-1 \mathrm{~b} . \quad \mathrm{lb}$.

$20 \quad 60 \quad \$ 200$

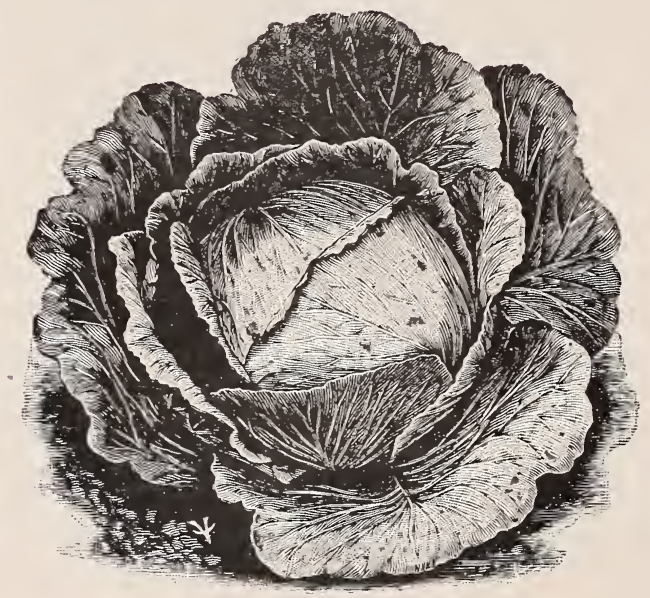

Jones' Late Flat Dutch. A very fine strain of this variety; heads large and more solid than the loose headed Flat Dutch 


\section{CABBAGE-CONTINUED.}

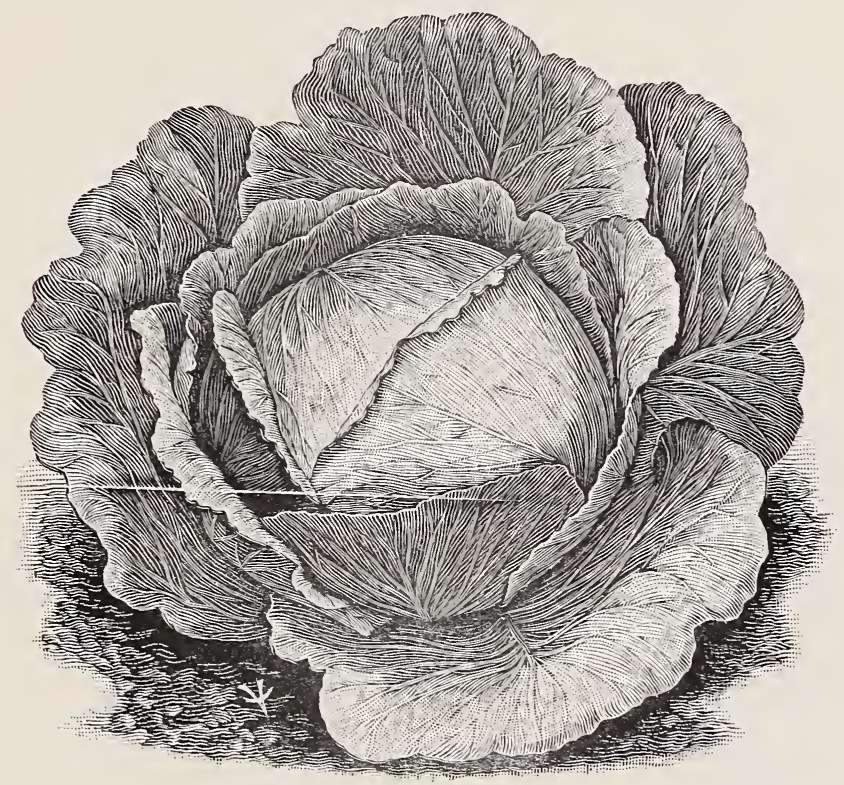

Danish Round Winter. The best cabbage for late spring sales and for

Oz. $\quad \mathrm{t} / 4-\mathrm{lb} . \quad \mathrm{lb}$. shipping; the heads of this variety are of medium size, are very solid and deep, and of a fine white color; their quality is superior and they keep better than any other sort.

Hollander

Large Late Drumhead. Very large solid head

$20 \quad 40 \quad 150$

Deep Head.

$15 \quad 40 \quad 150$

Stone Mason

$15 \quad 40 \quad 150$

Luxemburg or Hard Heading. Large, solid and good keeper

$20 \quad 60 \quad 200$

American Savoy.

$15 \quad 40 \quad 150$

Iron Head Savoy. See novelties.

$30 \quad 90 \quad 350$

Mammoth Rock Red. Large, round, solid, deep red.

$20 \quad 60 \quad 200$




\section{CARROTS.}

(One ounce to 150 feet of drill, about one pound per acre.)

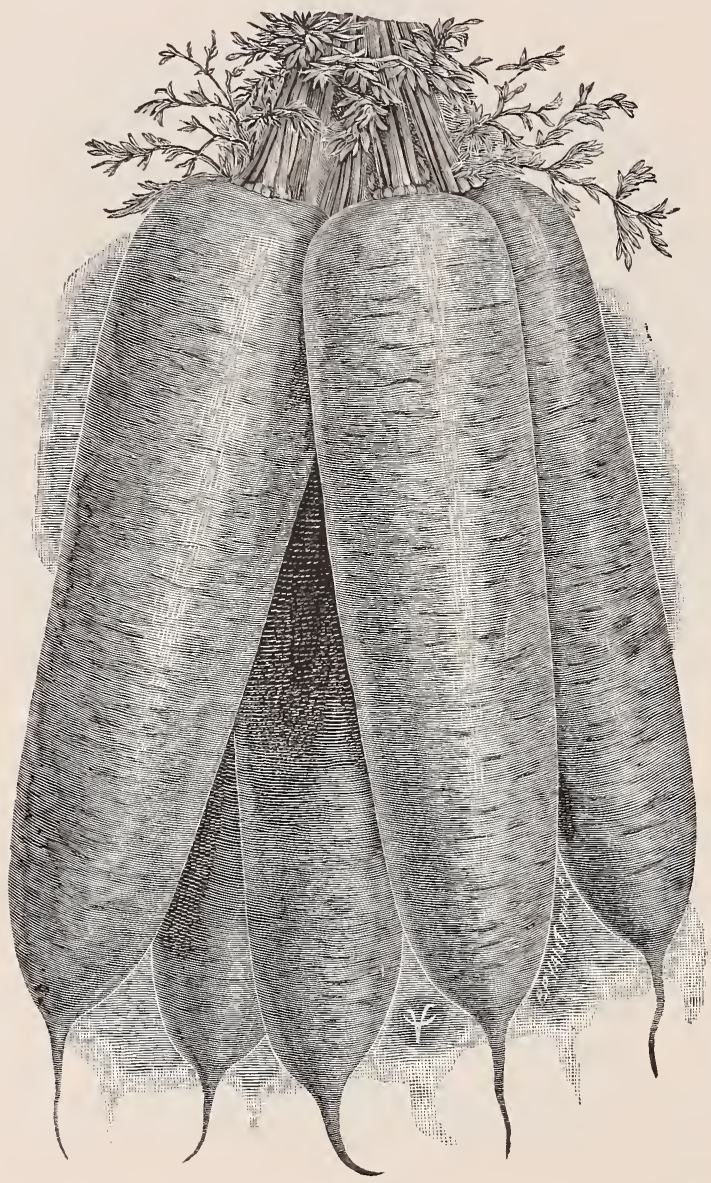

Oz. $\quad 1 / 4 \mathrm{tb} \quad \mathrm{tb}$

Danver's Half Long. Very productive and adapted tollall kinds of soil, roots smooth and handsome of medium length, deep orange color, flesh sweet and tender. 


\section{CARROTS-CONTINUED.}

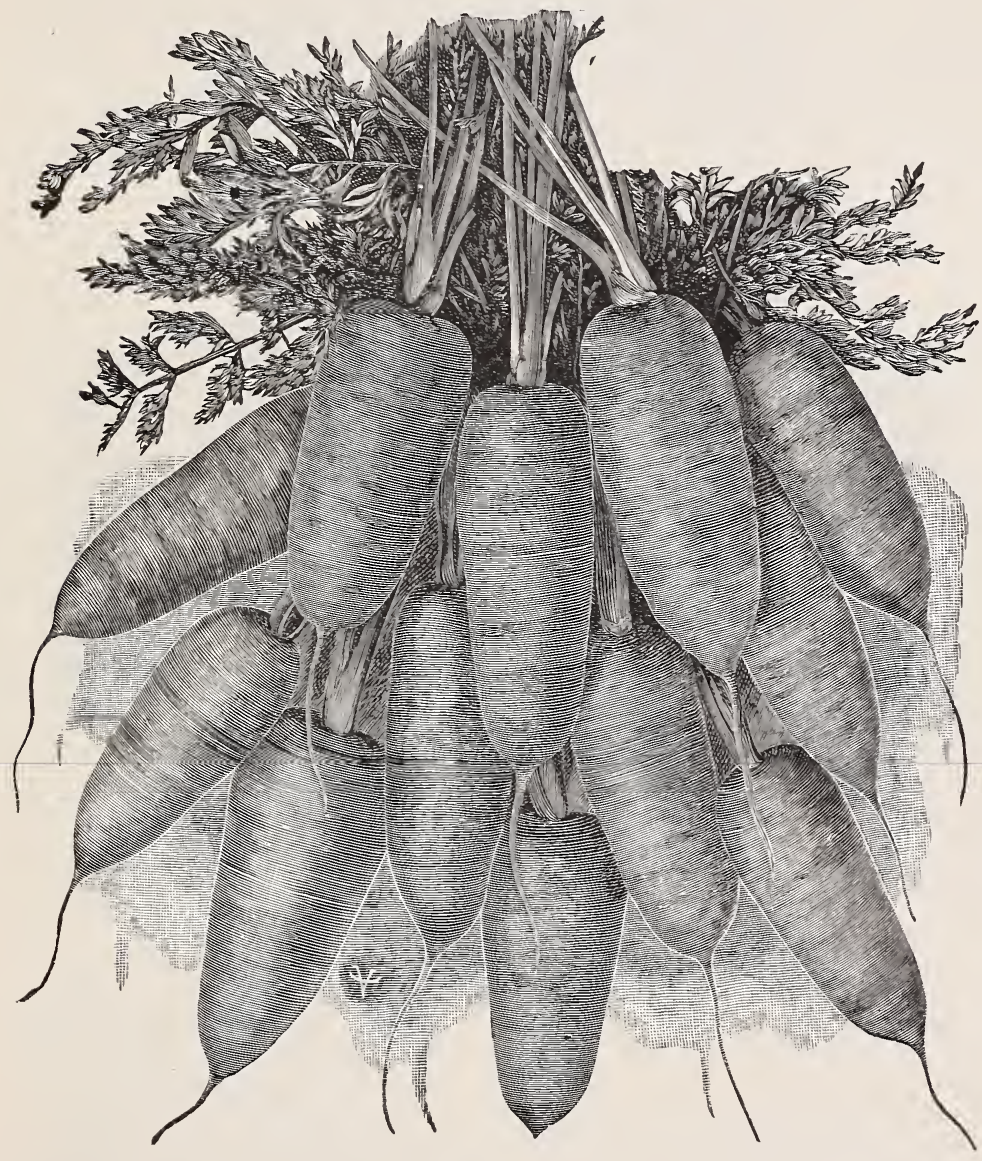

Chantena. The best for market garden; tops medium size; necks small; roots tapering slightly, but stump rooted; color deep orange red .............. 10

Oz. $\quad \mathrm{I} / 4 \mathrm{Hb}$ ib

Guerand or $0 x$ Heart. A thick carrot, very blunt on the end, easy to

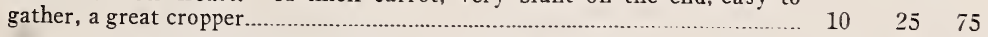

Early French Short Horn. Early, good bunching carrot....................... $10 \quad 25 \quad 75$ 


\section{CARROTS-CONTINUED.}

Improved Long Orange. A good cropper on deep mellow soil, the old standard for stock feeding

Oz. $\quad 1 / 4-1 b . \quad 1 b$.

White Intermediate
Long White Belgian. Stock carrot, very large.
CAUng Yellow Belgian. Stock carrot...
CAULOWER.

( $2 \frac{1}{2} \mathrm{oz}$. should produce enough plants for one acre.)

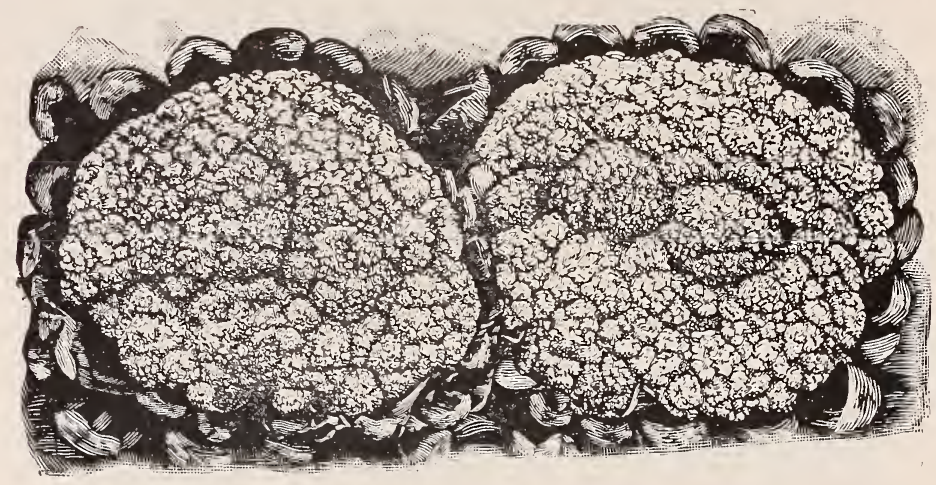

Early Snowball. The best; the heads are solid, compact and round, very white and kurd like.

Oz. $\quad \mathrm{r} / \mathrm{t}-\mathrm{lb} . \mathrm{lb}$. $\$ 200$

\section{CELERY.}

( $1 \mathrm{oz}$. of seed to 15000 plants; per acre $2 \mathrm{oz}$.)

White Plume. Early, uniformly white and free from green or hollow stalks

$20 \quad 60 \quad \$ 200$

Golden Self Blanching. Rich golden yellow, close compact growth, easily blanched, crisp and solid; better than White Plume.

$\begin{array}{lllll}30 & 1 & 10 & 4 & 00\end{array}$

Dwarf Golden Heart. Good main crop variety for fall and winter;

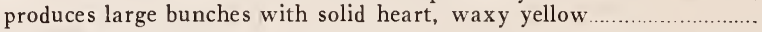

Evans' Triumph. This new variety is one of the best late sorts, very strong and vigorous with large, very white, crisp, tender and finely flavored stalks. It is late and requires the whole season to develop, and will keep longer than any other celery.

$20 \quad 60 \quad 200$

Kalamazoo Large Ribbed. Half dwarf white................................ $15 \quad 40 \quad 150$ 


\section{CELERY-CONTINUED.}

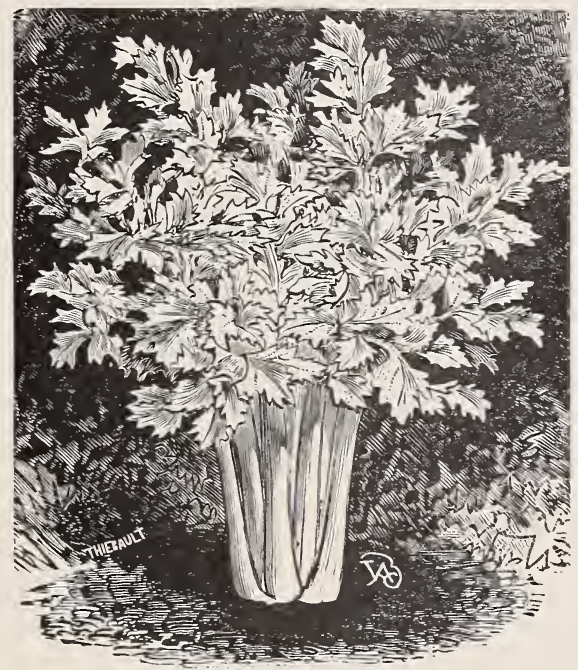

Perfection Hartwell. One of the best late sorts, producing large bunches of tall broad stalks, blanching to golden yellow.

Oz. $\quad 1 / 4-1 b . \quad 1 b$. Giant Pascol.

$15 \quad 40 \$ 150$

$20 \quad 50 \quad 160$

Soup or Cutting. Sown thickly in rows and cut when three or four inches high: used for flavoring soup.

$20 \quad 40 \quad 125$

\section{CELERIAC OR TURNIP ROOTED CELERY.}

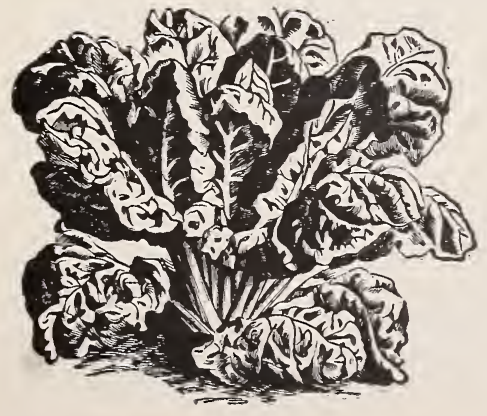

CORN SALAD-Feld Salat.

Used during the winter

Oz. $\quad 1 / 4-1 b . \quad 1 b$. and spring as a substitute for lettuce and spinach 


\section{SWEET CORN.}

Our sweet corn is grown for us in Conneticut by one of the best growers in the United States. The eastern grown corn is both earlier and sweeter than that grown in the west. While the cost is a little more the quality fully makes up for the difference in price. $1 / 4$ pint to 100 hills; 6 to 8 quarts per acre.

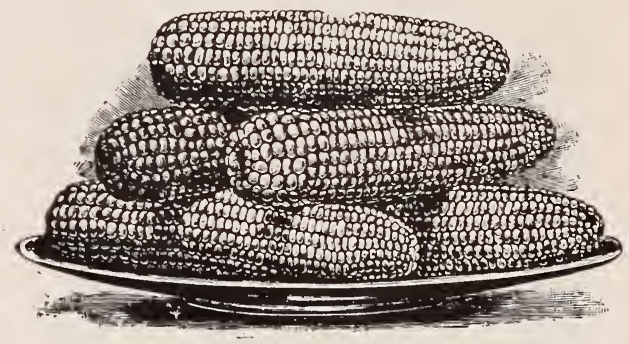

Early White Cob Cory. One of the best for the early market; ears fair size, cob white, and quality good

Qt. 4-Qts. Peck Bush. Oakview Early Market. Similar in general character to Mammoth White Cory but with larger ears and quite as early

$\begin{array}{llllll}20 & 75 & \$ 1 & 25 & \$ 4 & 50\end{array}$

Mammoth White Cory. Ears are 12 rowed; larger than White Cory and nearly as early

$\begin{array}{llllll}25 & 75 & 1 & 50 & 5 & 50\end{array}$

$\begin{array}{llllll}25 & 75 & 1 & 50 & 500\end{array}$

New Metropolitan. But a few days later than White Cory; ears set low, 10 to 12 rows, well filled to the top with large, tender kernels

$20 \quad 60 \quad 1 \quad 10 \quad 4 \quad 00$

Kendel's Early Giant. Large handsome ears; ready for use in 60 or 70 days..

$20 \quad 60 \quad 110 \quad 400$

Early Champion. Earliest large sweet corn; very sweet and tender

$20 \quad 50 \quad 90 \quad 350$

Burbank's Early Maine. Very early, large, pure white ears, of first class quality; good market corn.

$20 \quad 50 \quad 90 \quad 350$

Early Minnesota. Popular old variety.

$20 \quad 60 \quad 90 \quad 375$

Early Crosby. This is the sort so largely grown in Maine for canning and which has given Maine canned sweet corn its reputation for quality; crop short, supply limited

$20 \quad 60 \quad 100 \quad 375$

Black Mexican. When ready for use pure white, but the ripe grain is black; the sweetest variety and best for home garden

$20 \quad 60 \quad 110 \quad 400$

Perry's Hybride. Matures a little later than the Minnesota; ears very large.

$20 \quad 50 \quad 100 \quad 350$




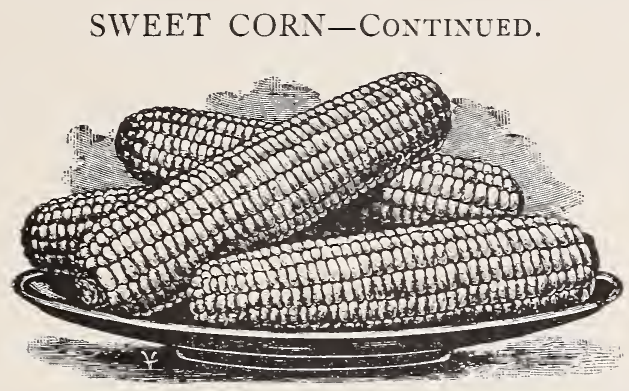

Old Colony. Matures a little earlier than Stowell's Evergreen, a great producer, best for fodder.

Qt. 4-Qts. Peck Bush.

Country Gentleman. Very small white cob, well covered with irregular rows of long slender kernels, very sweet.......

$20 \quad 60 \$ 1 \quad 10 \$ 400$

Early Evergreen. One to two weeks earlier than Stowell's Evergreen, ears large and of best quality

$25 \quad 70 \quad 120 \quad 450$

Stowell's Evergreen. The standard main crop variety; crop very short, supply limited.

$20 \quad 60 \quad 100 \quad 400$

$20 \quad 60 \quad 100 \quad 400$

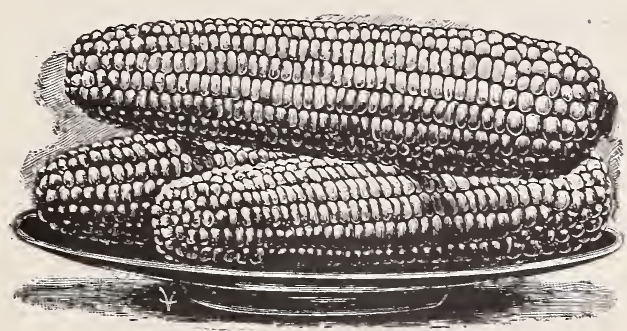

Mammoth. Produces the largest ears, quality sweet, tender and delicious

\section{CRESS.}

Extra Curled or Pepper Grass

$\begin{array}{ccc}\mathrm{Oz} . & \mathrm{x} / \mathrm{Hb} & \mathrm{1b} \\ 5 & 15 & 40\end{array}$

\section{CUCUMBER.}

(1 oz. to 100 hills; 1 th per acre.)

Rawson's Arlington White Spine. See novelties; 'sealed packages …....... $30 \quad \$ 100$ 


\section{CUCUMBERS-CONTINUED.}

Arlington White Spine

Oz. $\quad \frac{1}{4} / 4-1 b \quad$ tb

Improved Long Green.

$20 \quad 60 \quad \$ 200$

Nichols' Medium Green

$20 \quad 60 \quad 200$

Chicago Pickling. One of the best sorts for pickling

$20 \quad 60 \quad 200$

Boston Pickling or Green Prolific

$20 \quad 60 \quad 200$

Early Frame

$20 \quad 50 \quad 150$

Early Cluster

$20 \quad 50 \quad 150$

Early Russian

$20 \quad 50 \quad 150$

Cool and Crisp

$20 \quad 50 \quad 150$

Fordhook Pickling

$20 \quad 50 \quad 150$

Gherkin. A very small oval variety, prickly, quite distinct from all others

$25 \quad 75 \quad 250$

$\begin{array}{llll}20 & 60 & 2 & 00\end{array}$

\section{ENDIVE.}

( $1 / 4$ oz. to 100 feet of drill; $41 / 2$ tb per acre.)

Moss curled

$\begin{array}{llll}10 & 30 & \$ 1 & 00\end{array}$

Green Curled

$\begin{array}{llll}10 & 30 & 1 & 00\end{array}$

Broad Leaved Batavian

$10 \quad 30 \quad 100$

\section{EGG PLANT.}

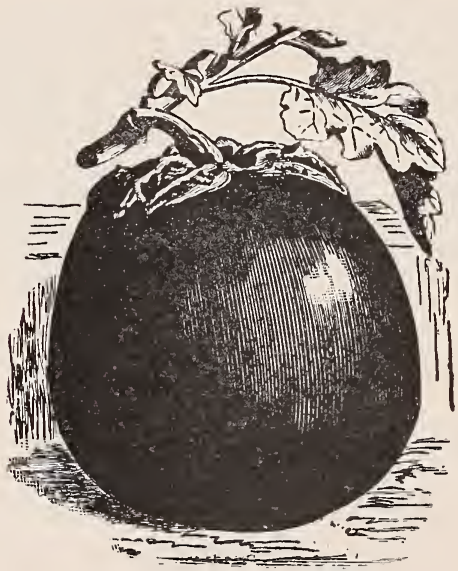

(1 oz. to 4000 plants; 4 oz. per acre.)

New York Purple. Very large and smooth, and fine dark color 


\section{KOHL RABI.}

( $1 / 3$ oz. to 100 feet of drill; 4 th per acre.)

White Vienna

Oz. $\quad 1 / 4-1 \mathrm{~b} \quad \mathrm{tb}$

$20 \quad 60 \quad \$ 200$

\section{LETTUCE.}

( $\mathrm{x} / \mathrm{toz}$. to 100 feet of drill; $3 \mathrm{fb}$ per acre.)

Grand Rapids Forcing. The best forcing and shipping variety, will produce more pounds of lettuce on the same space and stand longer after maturity than any known sort.

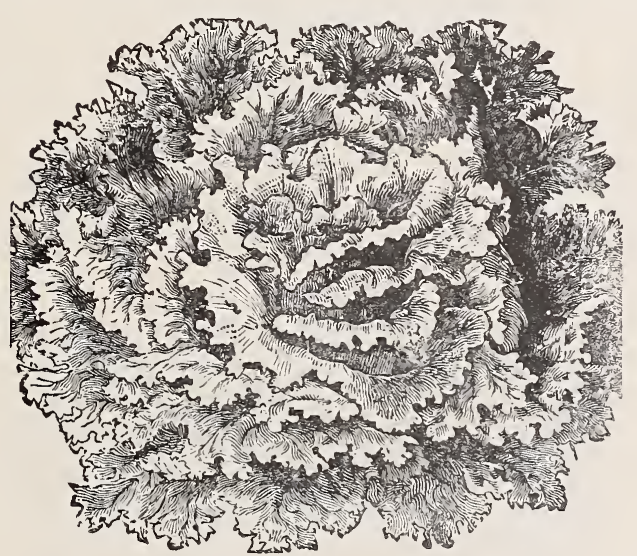

Early Curled Silesia. Very early, best for family Garden.

Black Seeded Simpson. Early, leaves large, thin, tender, growing in large loose clusters; good for forcing or early growing out doors for the early market.

Prize Head. Leaves are large, crimped, bright green, tinged with brownish red

White Cabbage

Hanson. Very large heading variety

Black Seeded Butter. Large, smooth leaved, solid heading sort, inner leaves beautifully bleached and very tender, of fine flavor................ 10

Premium Cabbage

Sensation

Big Boston. A very popular market gardener's sort; the plants are large, hardy, leaves smooth, thin, light green in color; in doors this forms a solid head, a less distinctively heading sort when out of doors 


\section{LETTUCE-ContINUED.}

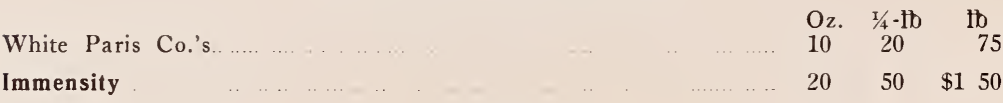

\section{LEEK.}

( $1 / 3$ oz. to 100 feet of drill, 4 th per acre.)

Large Musselburg

$\begin{array}{llll}10 & 30 & 1 & 00\end{array}$

Broad Scotch.

$10 \quad 30 \quad 100$

\section{MUSK MELON.}

( 1 oz. to 100 hills; 1 to $3 \mathrm{tb}$ per acre.)

Jackson First Market. As early as the Grand Rapids Early Market; fair size, nearly as large as the Osage and of the same shape, when ripe color light yellow, flesh green, very sweet and spicy, vines highly productive, but melons are poor keepers

Grand Rapids Early Market. Very early, large, yellow; good sellers on account of earliness and large size

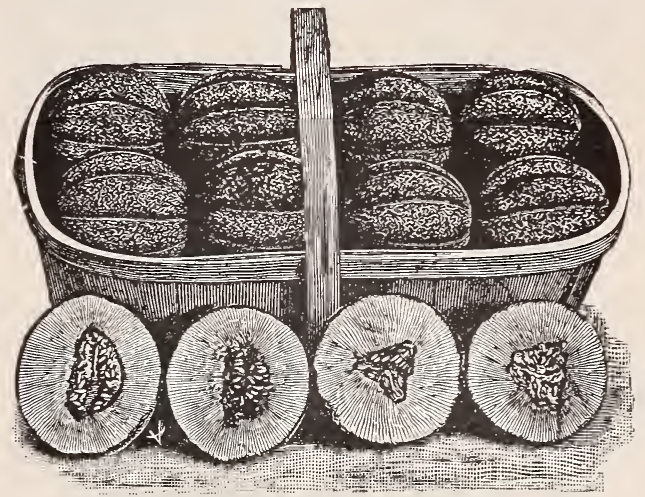

Paul Rose. For a shipping trade as a basket melon this new sort is unequalled; flesh yellow, very sweet and spicy

0sage. (Jones' Stock Seed.) Grown by a careful grower; this seed is saved from the very best and most perfect shaped melons, of the best quality; every melon must come up to the standard required; the 0sage is becoming more popular every year, and is the most profitable melon to grow on account of being a heavy yielder and a good shipper and the demand yearly increases

0sage. Grown from stock seed

$\begin{array}{llll}10 & 30 & 1 & 00\end{array}$




\section{MUSK MELON-CONTINUED.}

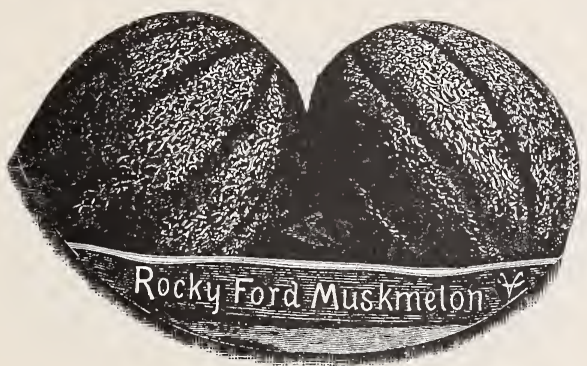

Rocky Ford

$\mathrm{Oz} . \quad \mathrm{r} / 4-\mathrm{tb} \quad \mathrm{tb}$

Extra Early Green Nutmeg. One of the best sorts for hotels and restaurants

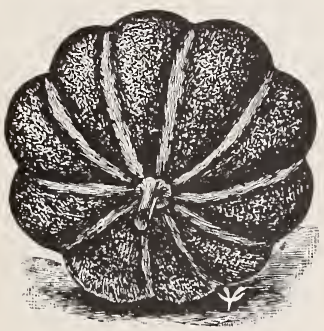

Emerald Gem.

$\begin{array}{llll}10 & 35 & 125\end{array}$

Extra Early Improved Hackensack

$10 \quad 25 \quad 80$

Bay View

$10 \quad 20 \quad 70$

Netted Gem

$10 \quad 25$

70

\section{WATER MELON.}

( $4 \mathrm{oz}$. to 100 hills; $1 \frac{1}{2}$ to $4 \mathrm{tb}$ per acre.)

Cole's Early. Very early and sweet; good for home market.

$10 \quad 20 \quad 60$

Triumph

$5 \quad 15 \quad 50$

Phinney's Early.

$5 \quad 15 \quad 50$

Black Spanish.

$5 \quad 15$ 


\section{WATER MELON-CONTINUED.}

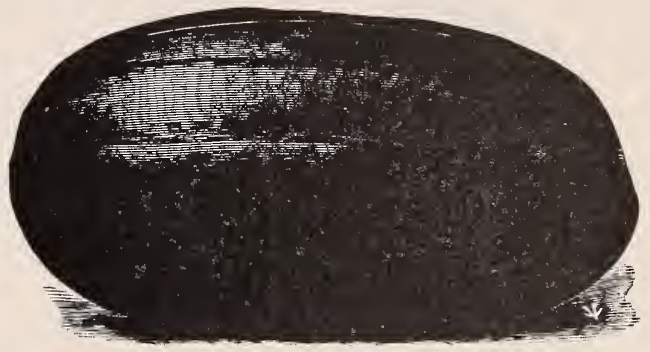

Oz. $\quad 1 / 4-16$

Monte Cristo or Kleckley's Sweet. A splendid variety for home garden or near market; fruit good size, long, somewhat tapering at the ends, skin dark green, flesh bright scarlet, very sweet, rind thin; not a good shipper ...

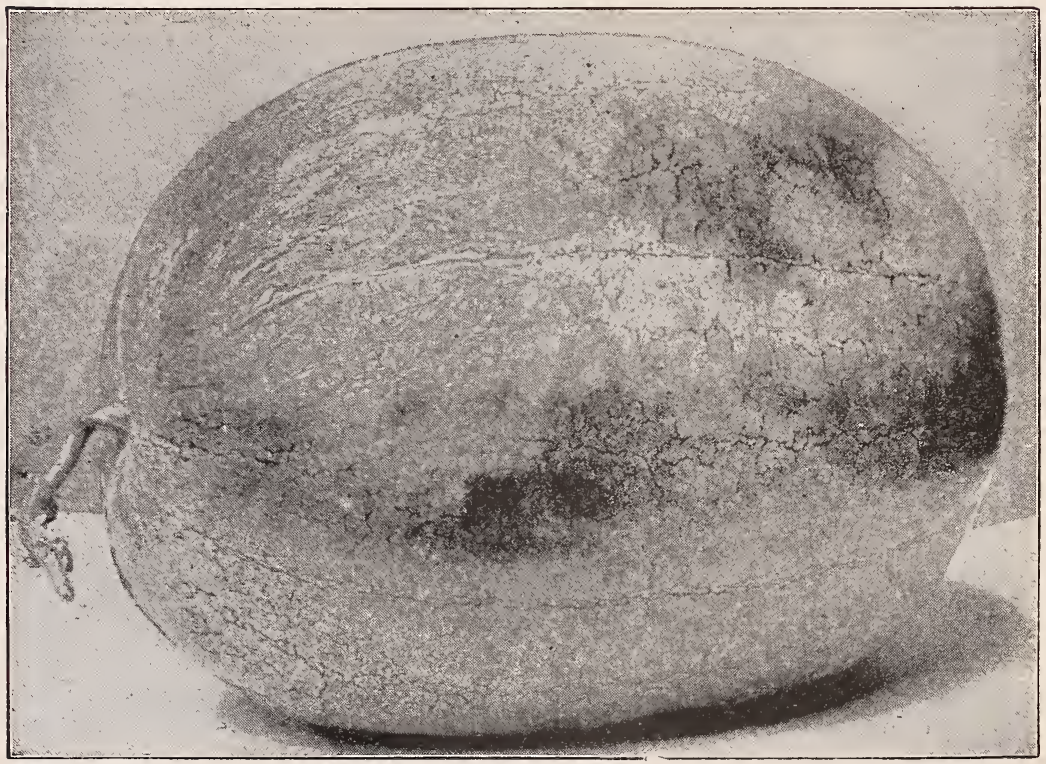




\section{WATER MELON-CONTINUED.}

Mountain Sweet...

Oz. $\quad 1 / 4-1 b \quad$ ib

Kolb's Gem....

$\begin{array}{lll}5 & 15 & 50\end{array}$

Peerless

$\begin{array}{lll}5 & 15 & 50\end{array}$

Dark Icing

$5 \quad 15 \quad 50$

Light Icing

$5 \quad 15 \quad 50$

Dixie

$5 \quad 15 \quad 50$

Hungarian Honey

$5 \quad 15 \quad 50$

Citron

\section{ONIONS.}

( $\mathrm{I} / 3 \mathrm{oz}$, to 100 feet of drill; 4 to $5 \mathrm{fb}$ per acre.)

Early Flat Red. A medium sized, early flat variety, very uniform in size and shape, moderately strong flavored.

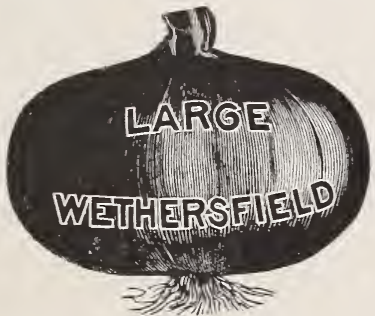

Large Red Wethersfield. A popular red sort, good keeper ................ $10 \quad \begin{array}{llll}40 & 100\end{array}$

Australian Brown. A small, early onion; one of the best keepers; quality good..

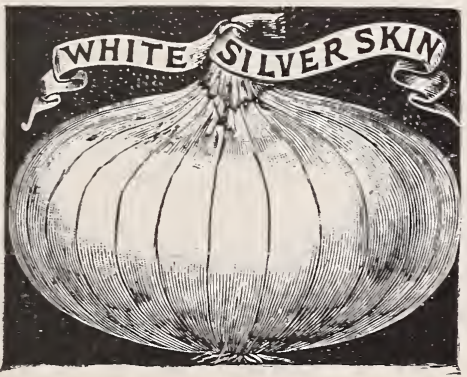

Philadelphia Silver Skin or Portugal. The best white onion for sets.. $\begin{array}{llll}20 & 50 & 175\end{array}$ 


\section{ONIONS-CONTINUED.}

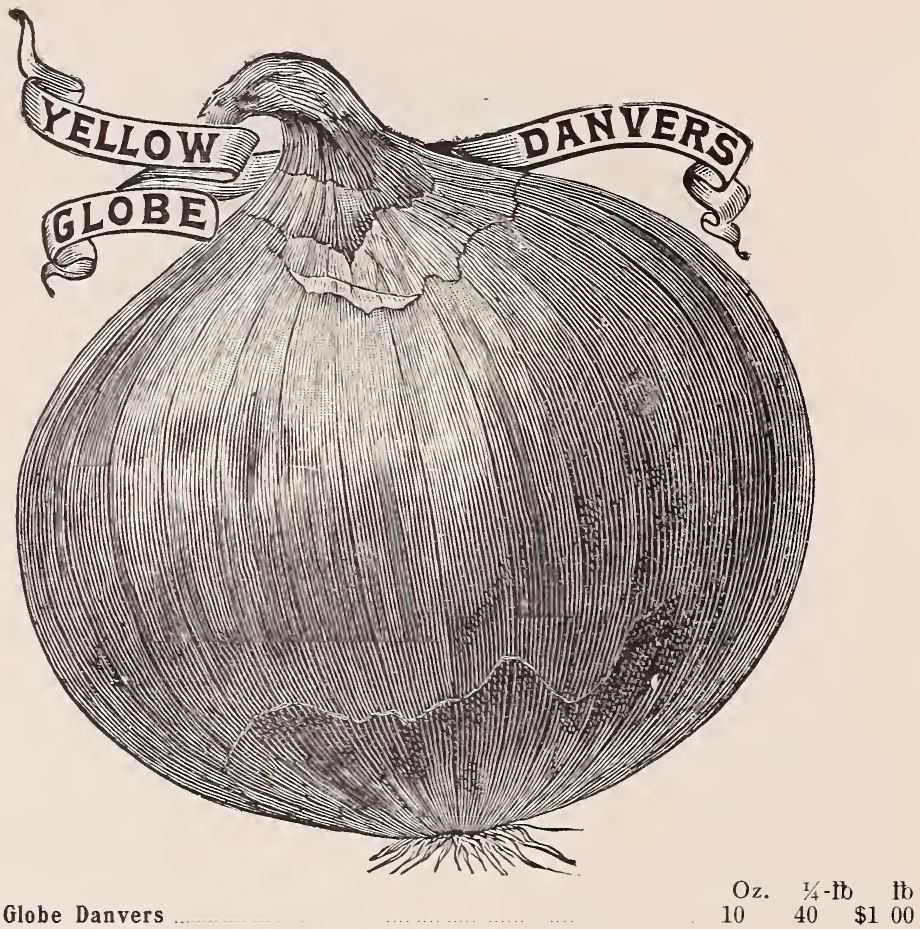

Yellow Globe Danvers

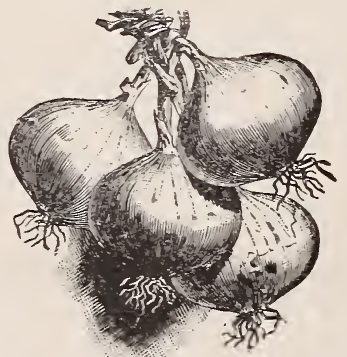

Adriatic Barletta. Small, early, white onion; used for pickling.. 


\section{ONIONS-CONTINUED.}

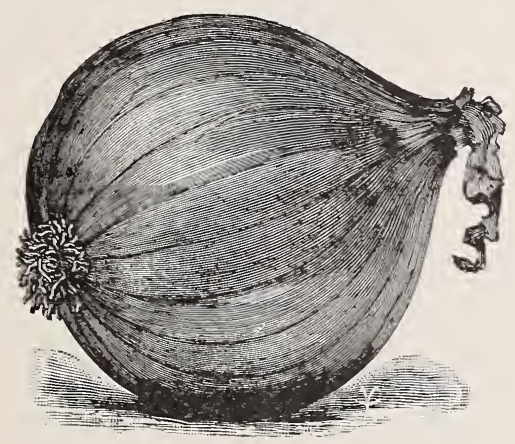

Michigan Yellow Globe. True globe, best on muck land, rich orange color

Oz. $\quad \mathrm{T} / 4-\mathrm{fb} \quad \mathrm{E} \mathrm{Eb}$

Prizetaker or Mammoth Yellow Spanish

$10 \quad 40 \quad \$ 125$

Southport Yellow Globe.

$\begin{array}{llll}10 & 30 & 1 & 10\end{array}$

$10 \quad 40 \quad 125$

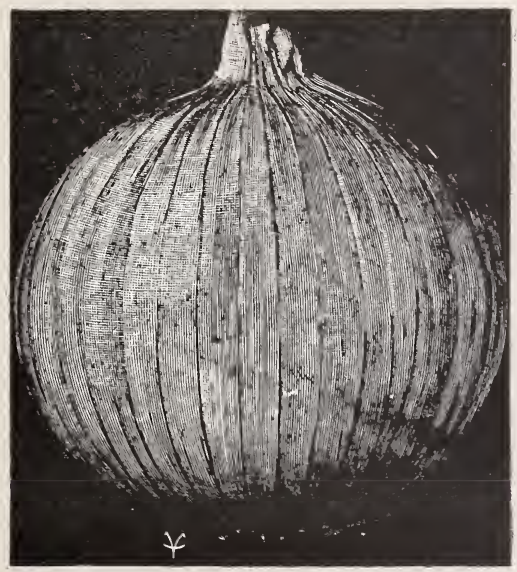

Southport Large White Globe. Large, solid and handsome. $\ldots \ldots \ldots \ldots$

Mammoth Silver King. Very large handsome white flat onion .......... $20 \quad 60 \quad 2000$ 


\section{ONIONS-CONTINUED.}

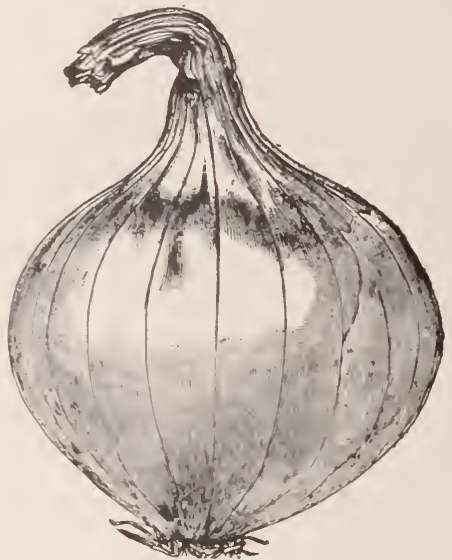

Southport Red Oz. 1/4- $\quad$ Oto to New Queen. Early, very white skinned; small, especially valuable for pickling

$\begin{array}{llll}15 & 40 & \$ 1 & 30\end{array}$

$15 \quad 50 \quad 175$

\section{PARSLEY.}

$\left({ }^{\pi}+\right.$ oz. to 100 feet of drill; 3 ith per acre.)

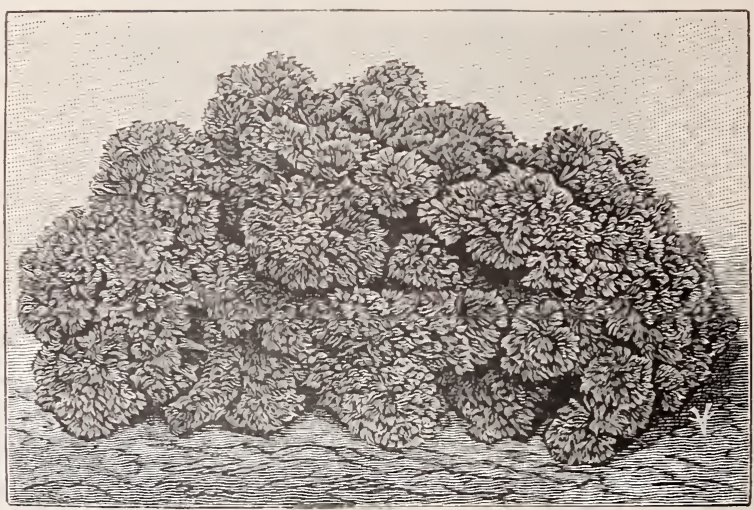

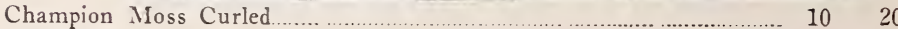

Fine Triple Curled. Fine curled and a stronger grower than Champion Moss Curled 


\section{PEAS.}

(1 pint to 100 feet of drill; 1 to 3 bush. per acre.)

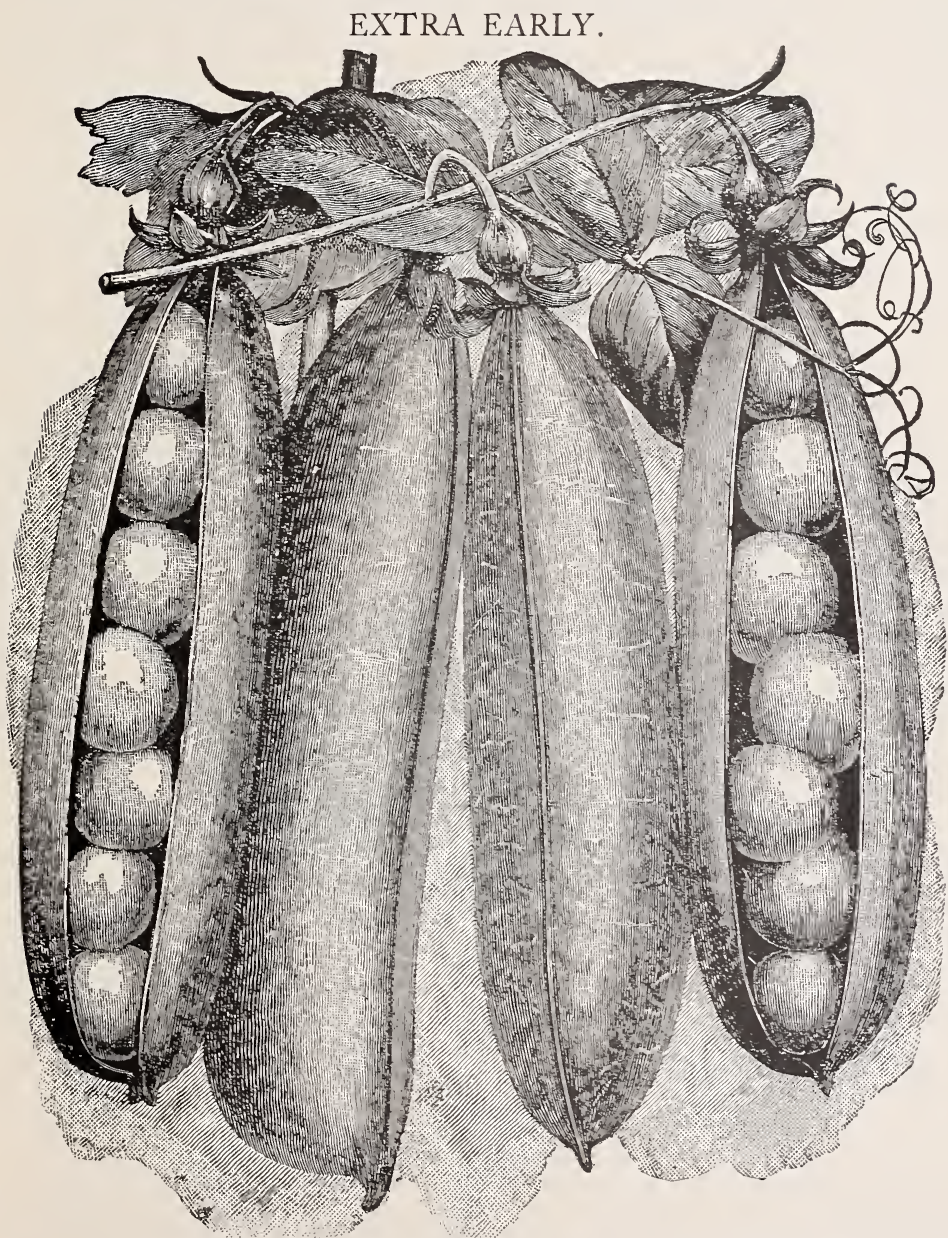

Qt. 4-Qts. Pk. Bush.

First and Best. Very early, popular for market and shipping $20 \quad 65 \quad \begin{array}{llllll}20 & \$ 4 & 75\end{array}$ 


\section{PEAS-CONTINUED.}

Alaska. The earliest and most popular blue pea, takes the lead now for early market pea.

Qt. 4-Qt. Pk. Bush.

Gradus. See novelties

$20 \$ 65 \quad \$ 120 \quad \$ 450$

Eclipse or Surprise. See novelties..

$\begin{array}{lllllll}40 & 1 & 50 & 3 & 00 & 12 & 00\end{array}$

Nott's Excelsior. Best early dwarf wrinkled pea, better bearers than American Wonder or Little Gem, quality just as good

$150 \quad 600$

American Wonder

McLean's Lettle Gem

Premium Gem

May Queen

\section{MAIN CROP.}

McLean's Advancer

Yorkshire Hero. Very productive; peas large.

Champion of England

Telephone. Best main crop variety; pods very long, peas large and sweet

Dwarf Telephone or Daisy.

Bliss' Everbearing

65

Pride of the Market. Vines of medium height, stiff, with large dark green leaves, bearing at the top very large pods well filled with large good flavored peas; one of the best large podded sorts.

Sharp's Queen. Pods very large, vines quite productive; excellent for market garden

$20 \quad 65 \quad 125 \quad 4 \quad 50$

Improved Stratagem. Vines 18 inches in height and very stocky, pods long, well filled with large peas.

Large White Marrowfat..

Black Eyed Marrowfat.

\section{PARSNIPS.}

I/4 oz. to 100 feet of drill; $3 \mathrm{tb}$ per acre.)

Hollow Crown. The old standard.

$\begin{array}{lll}\text { Oz. } & 1 / 4-\mathrm{tb} & \text { th } \\ 5 & 15 & 40\end{array}$

Long White Dutch or Sugar. Roots very long, white, smooth and tender 


\section{PEPPER.}

( 1 oz. to 5000 plants; $3 \mathrm{oz}$. per acre.)

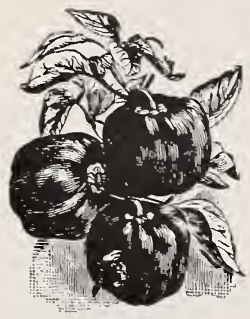

Ruby King. $4 \frac{1}{2}$ to 6 inches long, mild, one of the best for stuffed pickles

Oz. $\quad 1 / 4-16$

to

Sweet Mountain. Very productive, when ripe the peppers are a bright red, flesh thick, sweet and mild

$20 \quad 60 \quad \$ 200$

$20 \quad 60 \quad 200$

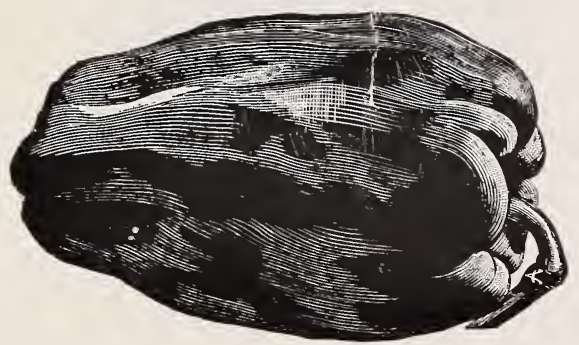

Large Bell or Bull Nose.

$20 \quad 60$

200

Cinese Giant Pepper. Fruit very large, scarlet, flesh thick, very mild, plant grows to a height of 2 feet; this sort is later and should be started early.

$\begin{array}{lllll}50 & 1 & 75 & 6 & 50\end{array}$

Long Red Cayenne.

$20 \quad 60$

200

\section{PUMPKIN.}

\section{( $1 / 3$ Qt. to 100 hills; 3 to 4 tb per acre.)}

Large Cheese or Kentucky Field. Popular for family use; flat shape.. $5 \quad \begin{array}{lll}5 & 40\end{array}$

Quaker Pie. Nearly oval, cream colored, best quality. 


\section{PUMPKIN-CONTINUED.}

Sweet Potato.

Oz. $\quad x / 4-1 b \quad$ ib

Common Yellow or Connecticut Field

$\begin{array}{lll}5 & 15 & 40\end{array}$

$5 \quad 10 \quad 30$

\section{RADISH.}

( $2 / 3 \mathrm{oz}$. to 100 feet of drill; 10 to $12 \mathrm{lh}$ per acre.)

Vick's Scarlet Globe. Good variety for forcing, equally good out doors.... $5 \quad 15 \quad 50$

Scarlet Conical. See novelties

$10 \quad 20 \quad 70$

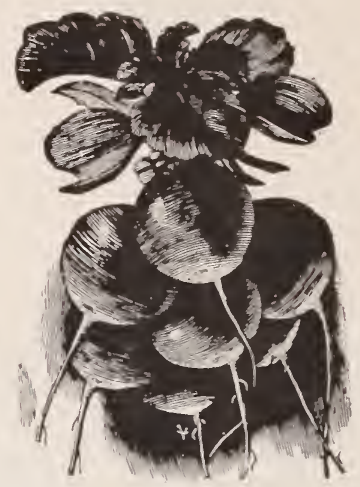

Scarlet Turnip White Tip. One of the earliest turnip shaped radishes, very handsome, good flavor; favorite on Grand Rapids market

$5 \quad 15 \quad 50$

Cincinnati Market. Long smooth, tops small, flesh very tender; does not become pithy or hollow.

$5 \quad 15 \quad 50$

Wood's Early Frame. Good early, long scarlet

$5 \quad 15 \quad 50$

French Breakfast.

$5 \quad 15 \quad 50$

Long Scarlet Short Top

$5 \quad 15 \quad 50$

Early Scarlet Turnip

$5 \quad 15 \quad 50$

Long White Vienna or Lady Finger.

$5 \quad 15 \quad 50$

Philadelphia White Box.

$5 \quad 15 \quad 40$

Chartier 


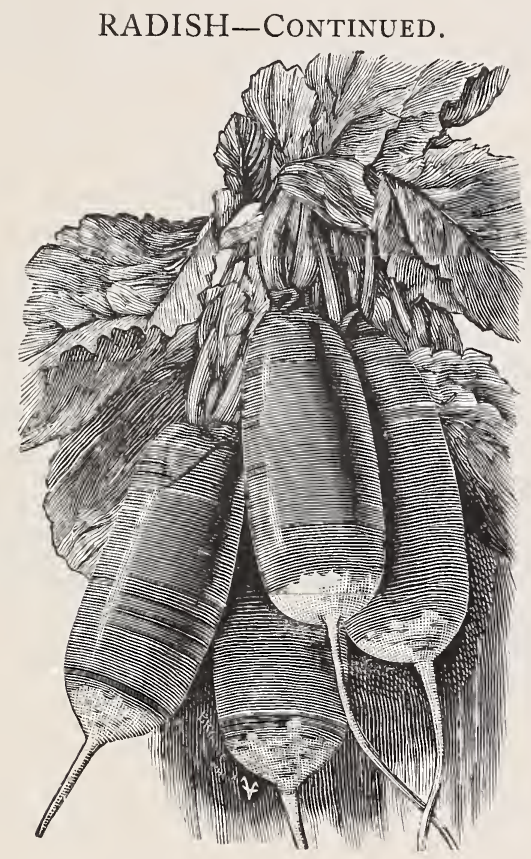

Long Brightest Scarlet. White tipped

$\mathrm{Oz}, \quad \mathrm{I} / 4-\mathrm{tb} \quad \mathrm{th}$

Giant White Stuttgart. A mammoth white summer radish

$5 \quad 15 \quad 50$

Long Black Spanish

… $515 \quad 50$

Round Black Spanish

$\begin{array}{lll}5 & 15 & 50\end{array}$

China Rose or Scarlet China. One of the best fall and winter radishes.... $5 \quad 15 \quad 50$

\section{SPINACH.}

( $1 / 2$ oz. to 100 feet of drill; $8 \mathrm{lb}$ per acre.)

Thick Leaved. Large dark green leaves, the most popular variety for the market

Bloomsdale or Savoy Leaved. Curly, thick and fleshy ……................... $5 \begin{array}{lll}5 & 10 & 20\end{array}$

Long Standing. Leaves smooth, dark green......................................... $5 \begin{array}{lll}5 & 10 & 20\end{array}$

$\begin{array}{lllll}\text { New Victory. Dark black green leaves; splendid for spring sowing …....... } & 5 & 10 & 20\end{array}$

Prickly Winter. Very hardy, leaves triangular or arrow shaped; hardiest for fall sowing 


\section{SALSIFY OR VEGETABLE OYSTER.}

( $3 / 4$ oz. to 100 feet of drill; 8 it) per acre.)

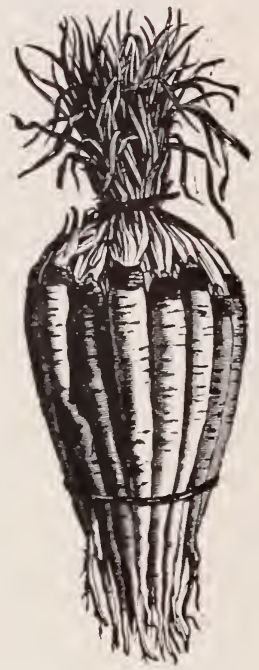

Mammoth Sandwich Island. This is a large strong growing plant, less liable to branch than the large white.

Oz. $\quad 1 / 4-1 b \quad$ ib Large White.

SQUASH.

SUMMER VARIETIES.

( $4 \mathrm{oz}$. to 100 hills; 2 th per acre.)

White Bush Scallop

Oz. $\quad 1 / 4$ tb $\quad \mathrm{tb}$

$10 \quad 20 \quad 70$

Mammoth White Bush. Twice the size of above

$\begin{array}{lll}10 & 25 & 80\end{array}$

Yellow Bush Scallop

$10 \quad 20 \quad 60$

Mammoth Yellow Bush. Large yellow, very early

$10 \quad 25 \quad 80$

Summer Crookneck. The old standard sort, very early.

$10 \quad 20 \quad 70$

Giant Summer Crookneck. Very large

$10 \quad 20$

70

FALL AND WINTER SQUASH.

( 8 oz. to 100 hills; $2 \mathrm{Hb}$ per acre.)

Boston Marrow. Good for autumn use ......... 


\section{SQUASH-CONTINUED.}

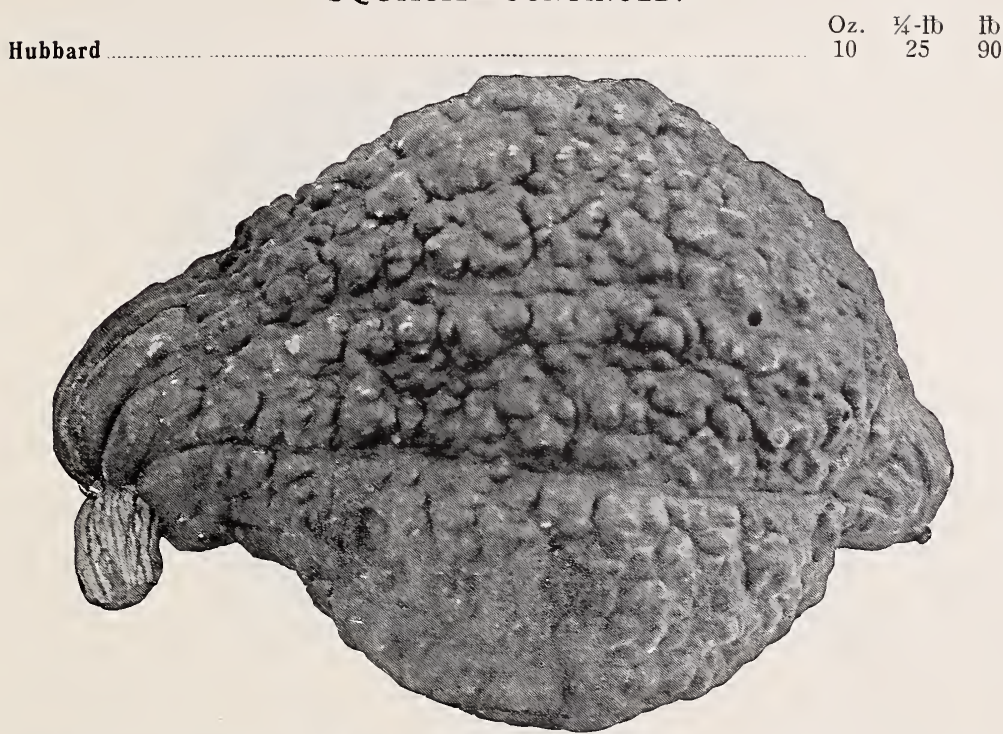

Chicago Warted Hubbard. Much larger and more warty than the old Hubbard

$10 \quad 30 \$ 100$

Sibley or Pikes Peak

$10 \quad 30 \quad 100$

Faxon. Very productive winter squash, fine keeper

$10 \quad 20 \quad 75$

Delicicus. See novelties, packages only.

Package 15 cts, 4 for 50 cts.

\section{TOMATOES.}

( $1 \mathrm{oz}$. to 4500 plants; 1 to $2 \mathrm{oz}$. per acre.)

Spark's Earliana. See novelties.

Oz. $\quad x / 4-16 \quad \mathrm{Hb}$

Dwarf Champion. Very early, fruit bright pink, smooth and regular

$40 \$ 130 \quad \$ 600$

Early Michigan

$\begin{array}{llll}20 & 75 & 2 & 75\end{array}$

Honor Bright. Bright red, good for shipping

$20 \quad 75 \quad 250$

Livingston's Favorite. Large smooth, productive; a good shipper and canner

$20 \quad 75 \quad 2 \quad 50$

Livingston's Perfection. Large size, productive, fine blood red; good canner

$20 \quad 60 \quad 200$

Livingston's Beauty. Large, smooth, fruit purplish pink, thick flesh; good canner

$20 \quad 60 \quad 200$

$20 \quad 60 \quad 200$ 


\section{TOMATOES-CONTINUED.}

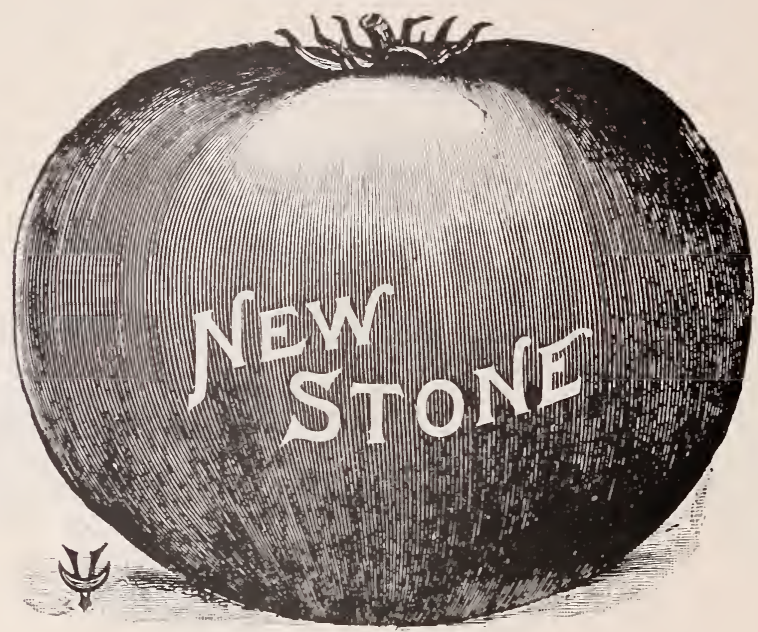

Oz. $\quad 1 / 4-1 b \quad t b$

New Stone. Very large, smooth, bright scarlet, solid; splendid canner. $20 \quad 60 \quad \$ 200$ Acme

$20 \quad 60 \quad 200$

Magnus. New, color of Beauty, but thicker leaves and more solid, very productive, matures quickly and will take first rank for early market

Golden Queen.

Red Cherry

Yellow Plum

\section{TURNIP.}

(1 oz. to 250 feet of arill; $1 \mathrm{th}$ per acre.)

New White Milan. Very early, white; the best for bunching ............. $10 \quad \begin{array}{llll}10 & 20 & 70\end{array}$

Purple Top Milan. Early ....................................................... $5 \quad 15 \quad 50$

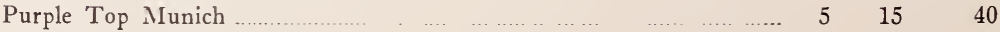

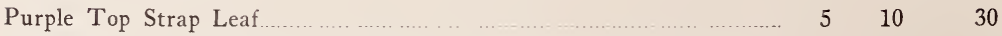

White Egg. Very handsome, good early or late turnip for the market. $\quad \begin{array}{llll}5 & 20 & 50\end{array}$ 


\section{TURNIP_CONTINUED.}

Purple Top White Globe.

$\begin{array}{ccc}\mathrm{Oz} . & \mathrm{I}+\mathrm{-tb} & \mathrm{tb} \\ 5 & 15 & 40 \\ 5 & 10 & 30 \\ 5 & 15 & 40 \\ 5 & 15 & 40 \\ 5 & 15 & 40 \\ 5 & 15 & 40 \\ 5 & 15 & 40\end{array}$

White Flat Dutch.

Cow Horn. Good stock turnip, heavy cropper

Large White Norfolk

Early White Stone

Yellow Stone.

Sweet German. Flesh white, hard and firm, sow early.

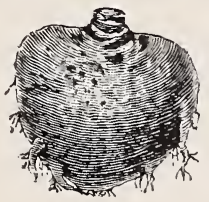

Yellow Aberdeen. Globe shaped, very large; good stock turnip

$5 \quad 15 \quad 40$

Robertson's Golden Ball. Small, early, fine quality

$5 \quad 1540$

Yellow Globe

$5 \quad 15 \quad 40$

\section{RUTABAGAS.}

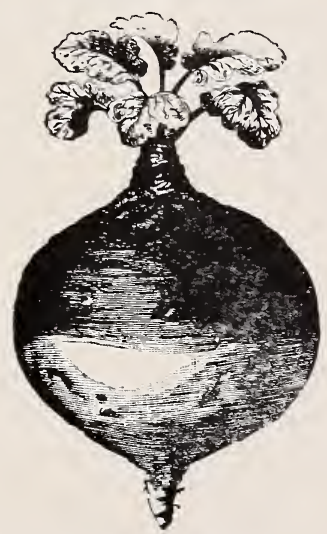

American Purple Top. Best yellow baga for market................... $5 \quad 15 \quad 40$

Carter's Imperial Swede

New Breadstone or Budlong. Early, white and sweet

White Sweet Russian. Large, very desirable for either table use or stock feeding. 


\section{HERBS.}

\begin{tabular}{|c|c|c|c|}
\hline Caraway & $\begin{array}{c}\mathrm{Oz} \\
10\end{array}$ & Summer Savory & $\begin{array}{c}\mathrm{Oz} \\
10\end{array}$ \\
\hline Dill ............... & $10 \quad 50$ & Sweet Marjoram & .. $10 \quad 90$ \\
\hline Lavender & $15 \$ 125$ & 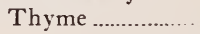 & $\ldots 20 \$ 200$ \\
\hline 3 road leaved & 10100 & & \\
\hline
\end{tabular}

\section{GRASS SEEDS.}

Medium Clover. 8 to $12 \mathrm{ft}$ per acre..

Mammoth Clover. 8 to $12 \mathrm{fb}$ per acre

Alsyke Clover. 6 th per acre.

White Dutch Clove. 6 th per acre

Crimson Trefoil. 10 to $15 \mathrm{fb}$ per acre.

Alfalfa or Lucerne. 15 to $20 \mathrm{fb}$ per acre

Kentucky Blue Grass. 2 bush. per acre

English Blue Grass. 1 bush. per acre..

Hungarian and Millet. $1 / 2$ bush. per acre

Orchard Grass. 2 bush. per acre

Red Top, fancy clean. $S$ to $10 \mathrm{Ht}$ per acre

" " unhulled. 15 to $20 \mathrm{fb}$ per acre

“ “ in chaff. 20 to $28 \mathrm{lb}$ per acre

Timothy. 6 Qts. per acre

Prices upon application

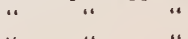

30 cts per $\mathrm{tb}$

Prices upon application “ ".

$\$ 160$ per bush.

Prices upon application ." ." ." $\$ 225$ per bush

150 ". "

125 " " "

60 " " "

Prices on application

\section{FIELD SEEDS.}

Dwarf Essex Rape. 1 to $5 \mathrm{fb}$ per acre

Cow Peas. $1 / 2$ to 1 bush. per acre

Whipperwill. Clay, early, black and mixed

Soy Beans. $1 / 2$ to $1 \mathrm{fb}$ per acre

Sorghum. Early, Amber, 3 to 4 th per acre

Kaffr Corn. White, 3 to $6 \mathrm{lb}$ per acre

\section{FIELD CORN.}

\section{( 4 Qts. per acre.)}

Poney Dent. Small, early, long kernel, medium stalk

Pride of the North. . Large ear and stalk, long kernel, 90 days

Smut Nose. Flint, very long ear.

Red Cob Ensilage. Very large, leafy stalk, used for fodder; corn

sown in rows at the rate of 1 to 2 bush. per acre.

Leaming Fodder. Earlier than Red Cob Ensilage.

\section{LAWN GRASS.}

(1 $\mathrm{ft}$ to 600 square feet; 3 to 5 bnsh. per acre.)

Hill Lawn Mixture. Especially adapted to light soils and shady situations. A thick velvety sod is very hard to grow on the light sandy soil of the hill residence district, but four years actual use has demonstrated that the Hill Lawn Mixture will do better, last longer and grow a thicker sod than any lawn mixture on the market.

Price $-1 \mathrm{fb}, 25 \mathrm{cts}$; $3 \mathrm{fb}, 60 \mathrm{cts}$. 


\section{LAWN GRASS-CONTINUED. CHICAGO PARK LAWN MIXTURE.}

It will prociuce an even, dense growth of permanent sward as early in the season as it is possible to do with seed. This mixture contains no annual grasses for making a quick show to the detriment of a good lawn but only those of lasting value and hardiness.

Price-1 1t, 25 cts.; 3 fb, 60 cts.; $10 \mathrm{lb}, \$ 1.75$.

Bone Flour. Very fine, clean, no smell; will produce a luxuriant growth of grass, making a thick, velvety sod.

Price-10 It, 50 cts.; $100 \mathrm{ft}, \$ 3.00$.

\section{FLOWER SEEDS.}

$\mathrm{Pkg}$. Oz.

Aster, tall mixed

“. dwarf mixed

Cosmos

Castor Oil Beans.

Morning Glory, common

Morning Glory, Japanese

Pansy, common mixed
10

10

10
10

5

Pansy, giant

Pkg.

Poppy

Petunia

10

10

Phlox

Sweet William

Verbena

Zennia

SWEET PEAS.

Apple Blossom, bright pink

America, blood red striped

Aurora, white striped with bright

Bride White

Boreatton, dark maroon

Blanch Ferry, pink and white

Blanch Burpee, pink and white

Brilliant, crimson scarlet

Cupid Dwarf, white.

Countess of Randor, lavender

Captain of the Blues, purplish blue.

Emily Eckford, reddish mauve.

Emily Henderson, pure white

Firefly, scarlet.

Golden Gate, pinkish mauve..

Gray Friar, general effect is gray .

Indigo King, rich purple maroon.

Lottie Hutchins, flaked pink on cream ground

Lady Mary Currie, new bright orange pink

Lovely Shell Pink

Maid of Honor, shaded light blue on white ground.

Primrose, creamy yellow

Queen of England, white

Royal Robe, bright rose pink

Red and White Striped

Salopian, deep crimson.

Shazada, dark maroon, shaded with purple

Senator, white ground, striped chocolate

Prize Mixture, the best

Large Flowering Mixed

$\begin{array}{rcr}\mathrm{Oz} . & \text { r } / \text { - } \mathrm{ft} & 1-\mathrm{tb} \\ \mathbf{5} & 15 & 40 \\ 5 & 15 & 50 \\ 10 & 20 & 70 \\ 10 & 20 & 70 \\ 5 & 15 & 40 \\ 5 & 15 & 40 \\ 5 & 15 & 40 \\ 10 & 20 & 60 \\ 5 & 15 & 40 \\ 10 & 20 & 60 \\ 10 & 20 & 70 \\ 5 & 15 & 40 \\ 5 & 15 & 40 \\ 5 & 15 & 40 \\ 5 & 15 & 40 \\ 5 & 15 & 40 \\ 5 & 15 & 40 \\ 10 & 20 & 70 \\ 10 & 30 & 100 \\ 5 & 15 & 50 \\ 10 & 30 & 100 \\ 5 & 15 & 40 \\ 5 & 15 & 40 \\ 5 & 15 & 50 \\ 5 & 15 & 40 \\ 10 & 20 & 70 \\ 10 & 30 & 100 \\ 5 & 15 & 50 \\ 10 & 30 & 100 \\ 10 & 25 & 70 \\ 5 & 10 & 30\end{array}$

Mixed, all colors 


\section{R O A A E F A R M A N D * GARDEN TOOLS *}

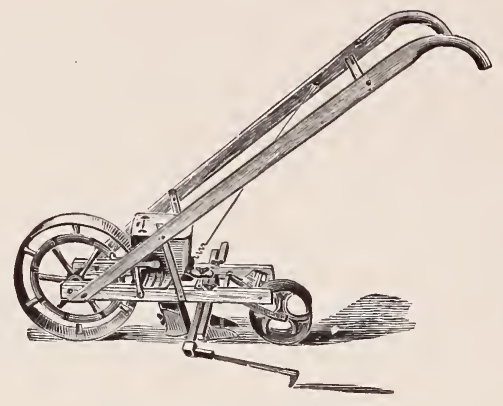

New Model Seed Drill.

The best drill for market gardeners. The best value in material, durability ana merit. Each Drill tested, crated and carefully packed for shipment. Price reduced to $\$ 7.50$.

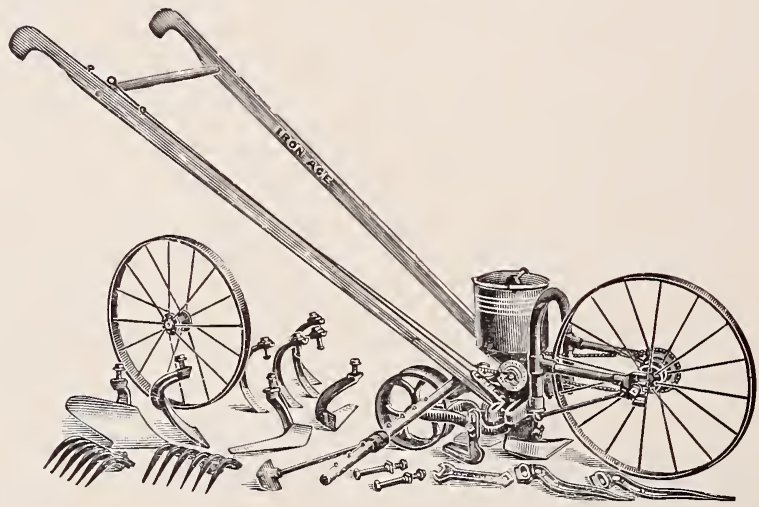

No. 4 Iron Age Combined Double Wheel Hoe Drill Seeder.

The most practical and complete combined tool on the market. Easy to adjust and operate, light and strong. Complete, $\$ 10.00$. As Drill Seeder, only $\$ 7.00$. 


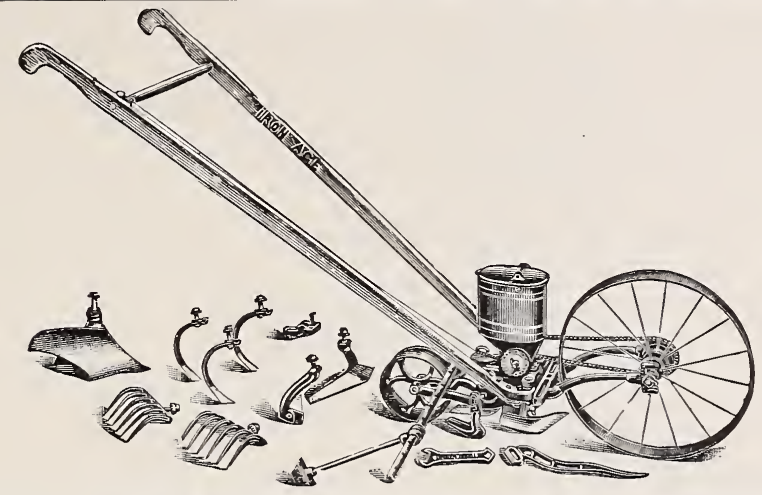

No. 15 Combined Single Wheel Hoe, Hill and Drill Seeder.

Will place the seed accurately either in the hill or drill, $\$ 10.00$. As Hill Dropper Drill, only $\$ 7.50$.

No. 18. Combined Single Wheel Hoe and Drill, similar to No. 47, without the Hill Dropping device, $\$ 9.00$.

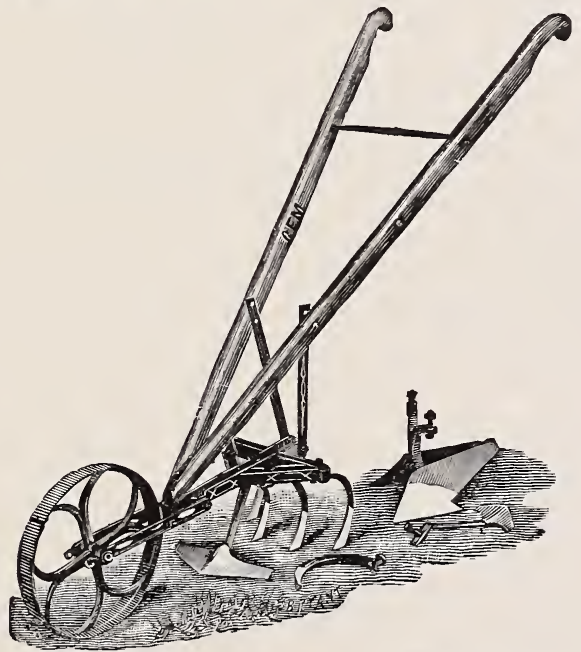

Gem of the Garden, Single Wheel Hoe.

Gem Double Wheel Hoe

Gem of the Garden Single Wheel Hoe 


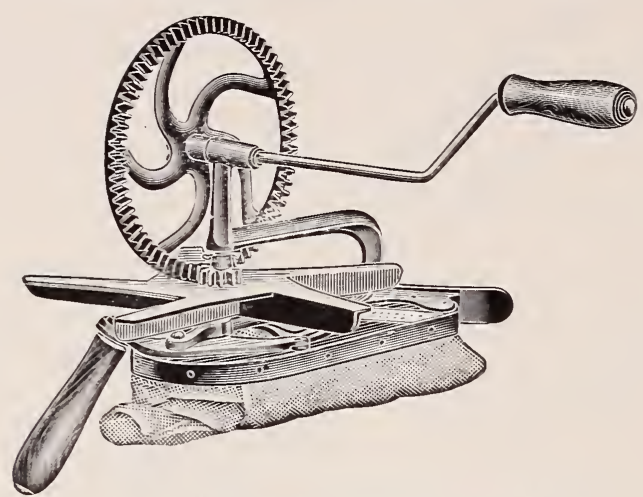

Premier Broadcast Seed Sower, $\$ 1.00$.

GARDEN TOOLS.

Asparagus Knives, each

Excelsior Weeders

Combination Weeders

Steel Trowels

Chisel Pruners $\begin{aligned} \$ 35 & \text { Dandelion Pullers } \\ 20 & \text { Lang's Weeders.. } \\ 25 & \text { Lane's Mole Trap } \\ 50 & \text { Putty Bulbs.......... } \\ 100 & \end{aligned}$

$\$ 20$

20

50

85

\section{ARMOUR'S FERTILIZERS.}

Armour's Grain Grower. Especially adapted for the growing of all cereals and for general farm use, quick and lasting.

Analysis-Ammonia per ct. 2
Available Phos. Acid

per ct. $S$ Potash $\mathrm{K}_{2} \mathrm{O}$
per ct. 2
Price per ton $\$ 22.00$

Fruit and Root Crop Special. For fruit trees and small fruits, grapes, etc., potatoes, beets, onions and all root crops.
Analysis-Ammonia per ct. 2
Available Phos. Acid per ct. 8
Potash $\mathrm{K}_{2} \mathrm{O}$ per ct. 5
Price per ton $\$ 28.00$

Bone, Blood and Potash. Made of dissolved bone meal, dried blood and with potash in the form of sulphate and nitrogen in the form of nitrate of soda added. It is especially adapted for the culture of celery, asparags, corn, fruits, grapes, tomatoes, cucumbers, melons, squash and wherever a very concentrated fertilizer is wanted.

Analysis-Ammonia

Available Phos. Acid

per ct. 8

Potash $\mathrm{K}_{2} \mathrm{O}$

Price per ct. 5 per ct. 7

per ton $\$ 36.00$

Wheat, Corn and 0 at Special. For all cereal crops.

Analysis-Ammonia per ct. 1

Available Phos. Acid per ct. 7 $\begin{array}{cc}\text { Potash } \mathrm{K}_{2} \mathrm{O} & \text { Price } \\ \text { per ct. } 1 & \text { per ton } \$ 18.00\end{array}$

Bone Meal. Made from pure finely ground bones, steamed in vats and thus rendered readily available in the soil, largely used for fruit, with either wood ashes or Muriate of Potash.

Analysis-Ammonia per ct 3 .
Available Phos. Acid

per ct. 24
Bone Phop. per ct. 52
Price

per ton $\$ 25.00$ 


\section{INSECTICIDE.}

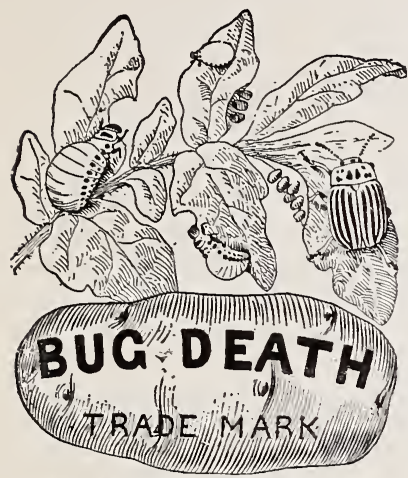

Pat. March 16 and Nov. 9, 1897 .

Pat. in Canada Nov. 2, 1897 , and Jan. 25, 1900.

Bug Death. This Insecticide and Plant Food Combined has been on the market for six years and its sales have shown a large increase each year. We can say to our customers that we give Bug Death our fullest endorsement. While the first cost to kill the bugs on an acre of potatoes is rather more than the arsenical insecticides, the results at harvesting time are entirely satisfactory, and where practical tests have been made the extra yield of marketable potatoes has more than paid the entire expense. It is non-poisonous, which makes it perfectly safe to use on all plants or vines.

Very beneficial results are obtained by using Bordeaux mixture in connection with Bug Death, and they can be mixed and sprayed on the vines at the same time, with any of the spraying machines on the market for that purpose. Bug Deatb prevents blight.

Reduction in Price. The manufacturers at the request of the trade and many consumers, have added a 100 -pound $\mathrm{keg}$, which will be much appreciated by the farmers, as it reduces the cost per pound.

Put up in packages as follows, with trade mark on each package:

1-1t package $\$ 15 \quad 121 / 2$ - 1 t package $\$ 100$

3-1t package

35 100-1b package 700

5-1t package

50 Perfection Shaker for applying Bug Death 65

Bug Death may be applied dry with the Perfection Shaker, or with a small bag made from burlap or gunny cloth having the right mesh; also mixed with water and sprayed as above stated. The best spray for fruit trees.

Hammond's Slug Shot. Kills the currant worm, potato bug, cabbage worm, slugs and aphis on roses, caterpillars, bugs on melons and cucumbers, cut worms, sow bugs, lice on fowls, curculio on plums, tobacco worms, etc.

Price per 5- $1 \mathrm{tb}$ package, $30 \mathrm{cts}$; $100-1 \mathrm{~b} \$ 3.50$.

Tobacco Dust. Fertilizer and insecticide, lice on lettuce.

Price per 5- $1 \mathrm{~b}, 25$ cts.; 15-lb, 60 cts.; 100- $1 \mathrm{~b}, \$ 2.00$.

Twemlow's Old English Glazing Putty Semi-Liquid and Elastic. For bedding glass in sash or for filling cracks or seams in roof joints or frames of greenhouses or hot beds; lasts from 5 to 7 years.

Price per 1 gallon, $\$ 1.25 ; 5$ gallons, $\$ 1.20$ per gallon.

\section{JONES' FLIZIP.}

The great fly remedy for cows, horses and sheep. How would you like to be a cow and have the flies bite you. Think of the long weary summer days and warm dreary nighs of torment. It is not only the protection of your animals from flies, lice, mites and other vermin but it is money in your pocket to use Flizip; it is cheap, as one gallon properly applied will keep 25 cows free from flies for two weeks. The feed saved will more than pay the cost and you will gain in the increase of flesh and increased production of milk.

Price per 1 gallon, $\$ 1.00$. Express prepaid to Michigan points. 


\section{HORSE-ENE.}

The best and icheapest horse and cattle ointment made. Will positively cure galls, cuts, scratches, mud scalds, quarter cracks, sore shoulders, necks, and backs on horses, foot rot on sheep and cattle, sore teats on cows, mange on dogs and all skin diseases.

Price per box, 15 cts.; 2 boxes, 25 cts. Special price on boxes 1 and 5 pounds.

\section{THISTLEINE.}

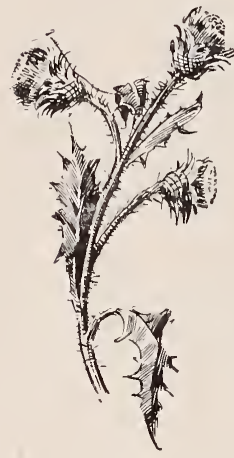

The great Thistle and Weed Killer. Thistleine is a chemical preparation and when applied to the leaves and stalks of Canadian Thistles, Burdock, Dandelion, Johnson grass, ¿Mullen Plantain or other fibrous plants, will absolutely land positively kill them root and branch. Canada thistle, the farmer's greatest enemy can be cheaply and easily overcome. Thistleine follows the fibers of the plant and works all through the roots and will kill every rootlet. Thistleine should be dissolved in boiling water. IOne pound will make one gallon of liquid strong lenough to kill Canada Thistle. It should then be applied with a spray pump to the leaves and stalks. For killing weeks in the walks and driveways and city streets it is unequalled. Your money back if it don't do the work.

Price-5-1b can, $\$ 2.00$.

\section{WEIGHTS OF VARIOUS ARTICLES.}

Barley

Per bush.

Beans

48

60

Buckwheai

Canary Seed

Castor Beans

Clover Seed

Corn, field, shelled

." " on ear

. sweet, sold by measured bushel.

Flax Seed

Grass, Rhode Island Bent.

“ Creeping Bent

“ Red Top (in chaff)

". $\quad$ (cleaned from chaff)..

“ Meadow Foxtail.

“ Tall Meadow Oat

“ Awnless Brome

“ Orchard

“ Hard Fescue

، Tall
Per bush.

Grass, Sheep's Fescue.................... 12

" Meadow Fescue or English Blue Grass......................... 22

“ Perennial Rye.................... 20

“. Timothy ................................ 45

.. Wood Meadow........................ 14

“. Kentucky Blue..................... 14

“. Fowl Meadow ..................... 12

“ Rough Stalked Meadow....... 14

“. Hemp Seed.............................. 44

Hungarian ..................................... 48

Millet, Gorman or Golden ............ 50

Millet .............................................. 50

Peach Pits ...................................... 50

Peas, smooth................................ 60

.. wrinkled.. ........................... 56

Rape ........................................... 50

Rye .................................................... 56

Vetches or Tares............................. 60 



\section{THISTLEINE HILLS CANADA THISTLES}

